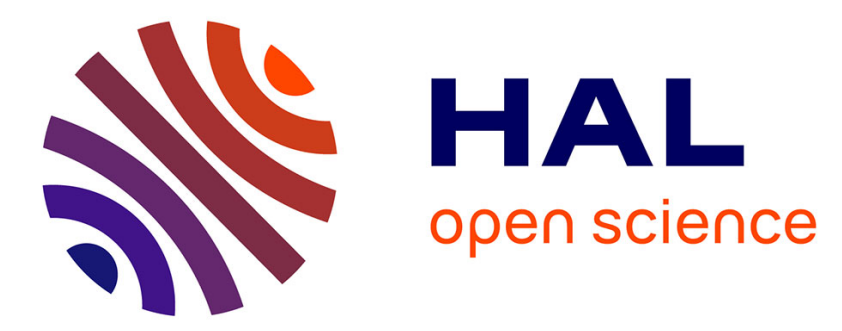

\title{
Initial geometry and paleoflow reconstruction of the Yamansu skarn-related iron deposit of eastern Tianshan (China) from paleomagnetic and magnetic fabrics investigations
}

Guangrong Li, Stanislas Sizaret, Yannick Branquet, Luc Barbanson, Yan

Chen, Bo Wang, Changzhi Wu, Lianxing Gu, Liangshu S. Shu

\section{To cite this version:}

Guangrong Li, Stanislas Sizaret, Yannick Branquet, Luc Barbanson, Yan Chen, et al.. Initial geometry and paleoflow reconstruction of the Yamansu skarn-related iron deposit of eastern Tianshan (China) from paleomagnetic and magnetic fabrics investigations. Journal of Southeast Asian earth sciences, 2014, 93, pp.1-14. 10.1016/j.jseaes.2014.06.009 . insu-01102324

\section{HAL Id: insu-01102324 \\ https://hal-insu.archives-ouvertes.fr/insu-01102324}

Submitted on 19 Jan 2015

HAL is a multi-disciplinary open access archive for the deposit and dissemination of scientific research documents, whether they are published or not. The documents may come from teaching and research institutions in France or abroad, or from public or private research centers.
L'archive ouverte pluridisciplinaire HAL, est destinée au dépôt et à la diffusion de documents scientifiques de niveau recherche, publiés ou non, émanant des établissements d'enseignement et de recherche français ou étrangers, des laboratoires publics ou privés. 
Initial geometry and paleoflow reconstruction of the Yamansu skarn-related iron deposit of eastern Tianshan (China) from paleomagnetic and magnetic fabrics investigations

Guangrong LI $^{\mathrm{a}, \mathrm{b}, \mathrm{c}}$, Stanislas SIZARET ${ }^{\mathrm{a}}$, Yannick BRANQUET ${ }^{\mathrm{a}}$, Luc BARBANSON ${ }^{\mathrm{a}}$, Yan $\mathrm{CHEN}^{\mathrm{a}, \mathrm{c}}$, Bo WANG ${ }^{\mathrm{b}}$, Changzhi $\mathrm{WU}^{\mathrm{b}}$, Lianxing GU${ }^{\mathrm{b}}$, Liangshu $\mathrm{SHU}^{\mathrm{b}}$

a Institut des Sciences de la Terre d'Orléans, UMR 7327-CNRS/Université d'Orléans/BRGM, 1A rue Férolerie, F-45071 Orléans, France

${ }^{\mathrm{b}}$ State Key Laboratory for Mineral Deposits Research, Department of Earth Sciences, Nanjing University, Nanjing 210093, China

${ }^{c}$ College of Earth Science, East China Institute of Technology, Nanchang, 330013, China.

* Corresponding author. Address: ISTO, 1A rue Férollerie, 45071 Orléans CEDEX 2, France. Tel. :332 384943 67. E-mail address: stanislas.sizaret@univ-orlenas.fr

\section{Abstract}

This study aims to uses paleomagnetic and anisotropy of magnetic susceptibility (AMS) methods to recognize the initial deposit position and to track the paleoflow at the origin of an iron skarn-related deposit. The Yamansu deposit is located in eastern Tianshan. This province has a substantial mining potential for $\mathrm{Fe}-(\mathrm{Cu})$ skarn, $\mathrm{Cu}-\mathrm{Ni}$ and V-Ti orthomagmatic deposits, and orogenic Au lodes. Recent publication dates the 
Yamansu deposit at $323 \mathrm{Ma}$, and uses this deposit to define a model of Submarine Volcanogenic Iron Oxide (SVIO) deposits (Hou et al., 2014a, b). In the proposed model the Yamansu stratoïd ore bodies formed horizontally within the central venting part of a large submarine composite volcano in a back-arc environment. However, at Yamansu the ore bodies are tilted vertically by the large scale dextral strike-slip faulting during the Permian. The Carboniferous positions are thus overprinted and unknown. Understanding the initial geometry and structures of the Yamansu deposit is then necessary to test and/or improve the proposed SVIO model. Field observations evidence an emplacement of the basalt as sill and their alteration into skarn. Magnetic mineralogy results show that the magnetic remanence and susceptibility are carried by magnetite. Paleomagnetic measurements on massive garnet skarn and basaltic sill distinguish two groups of samples. The higher coercivity samples give a mean remanence direction that is compatible with regional Late Carboniferous directions after bedding correction. This result indicates that both the basaltic sill and the massive garnet skarn were horizontal when formed. The AMS results agree with the paleomagnetic data because the magnetic foliations after bedding correction are horizontal and the well-defined magnetic lineation suggests the existence of a horizontal fluid flow during metasomatism. These results indicate that the basaltic sill horizontally intruded the Carboniferous limestones intercalated within the volcanic pile. Metasomatic iron-rich fluid probably ascended along a pre-existing fault and was injected horizontally into the limestone and sill, and then caused extensive 
skarnization and deposited the magnetite before tilting due to the Permian right-lateral strike-slip.

Key words: anisotropy of magnetic susceptibility, paleomagnetism, eastern Tianshan, Yamansu, skarn-related iron deposit, ore genesis, Late Paleozoic, Permian strike-slip.

\section{Introduction}

As an important metallogenic province, the eastern Tianshan can be divided into four units (Fig. 1): the Dananhu arc belt, Aqishan-Yamansu belt, Middle Tianshan terrane and South Tianshan terrane. These units have been formed by the accretion-collision of arcs and microplates from the Ordovician to Carboniferous (Charvet et al., 2007, 2011; Wang et al., 2010). By the end of the Carboniferous all of the units were welded and deformed. Major dextral shearing occurred during the Permian due to the relative displacement of the Jungar and Yili blocks, below Tarim and Siberian (Wang et al., 2007, Wang et al., 2014). In spite of compressive Cenozoic re-activation and subsequent uplift, those different tectonic units are still delineated by large Permian strike-slip faults which accommodated the dextral movement between the Tarim and Siberian blocks.

The Carboniferous and Permian were productive periods for mineralization in the eastern Tianshan. Most mineralization correspond to skarn-related iron deposits, 
porphyry $\mathrm{Cu}$ deposits, orthomagmatic $\mathrm{Cu}-\mathrm{Ni}$ and $\mathrm{V}-\mathrm{Ti}$ deposits with associated mafic/ultramafic complexes, and orogenic and epithermal Au deposits. Three main metallogenic stages have been identified (Zhang et al., 2008 and references therein):

(1) An early subduction-island arc stage within the Dananhu arc (360-320 Ma) leading to the formation of the porphyry $\mathrm{Cu}$ deposits such as the Yangdong and Tuwu porphyry $\mathrm{Cu}$ deposits (Zhang et al., 2004; Han et al., 2006) and base metal volcanic massive sulfide deposits. In the Late Carboniferous, the magmatic front migrated southward to form the Aqishan-Yamansu arc during the closure of the ancient Tianshan ocean (Ma et al., 1997; Hou et al., 2006; Wu et al., 2006; Zou et al., 2006; Hou et al., 2007).

The 320-280 Ma time span corresponds to the collisional-accretionary tectonic stage between arcs and micro-plates. During this tectonic phase major thrusts, folds and co-genetic foliations developed. Except for the main 290-282 Ma ore-forming stages of the Kanggur orogenic-type gold deposit (Zhang et al., 2003), this Late Carboniferous-Early Permian period is nearly devoid of mineralizing events throughout the eastern Tianshan.

(2) A post-collisional stage (280-245Ma) is marked by shearing along the major right-lateral Permian strike-slip faults. This stage corresponds to the formation of world-class orthomagmatic $\mathrm{Cu}-\mathrm{Ni}-\mathrm{Ti}-\mathrm{V}$ deposits associated with mafic-ultramafic complexes (Wang et al., 2008 ${ }^{\mathrm{a}}$; 2008 ${ }^{\mathrm{b}}$; Wang et al., 2009; Mao et al., 2011). Some of the ore-bearing intrusions are typical sheeted syntectonic intrusions in the Permian dextral shear zones (Branquet et al., 2012). This period also marks the peak of gold 
mineralization throughout eastern Tianshan. The gold deposits are either lodes of the shear-zone-type in the Permian strike-slip zones or veins of the epithermal/magmatic hydrothermal type related to the Permian volcanism and intrusions (Pirajno et al., 1997; Zhang et al., 2000; Wang et al., 2005; Zhang et al., 2008).

(3) A final Triassic stage (240-220 Ma) during which Fe-V-Ti oxide ores formed in mafic/ultramafic intrusions such as the Weiya deposit (Zhang et al., 2005).

In the eastern Tianshan, many deposits of iron, gold or silver are reported to be of the "skarn-type" (Mao et al., 2011; Zhang et al., 2008). As explained below and to avoid confusion, we will favor the more generic term "skarn-related" to qualify these iron-(copper) deposits in the following sections. The skarn-related $\mathrm{Fe}-(\mathrm{Cu})$ deposits in the Aqishan-Yamansu arc belt are reported to have been formed during the Carboniferous before Permian dextral shearing (Li et al., 2004). The Yamansu skarn-related magnetite deposit is one of the most studied in the eastern Tianshan province. It is hosted in Carboniferous limestone and a basaltic formations . Recent studies (e.g. Li et al., 2004; Hou et al, 2014a) show that, despite the massive calc-silicate deposition of $\mathrm{Ca}$ and Fe-rich garnets and pyroxenes, these deposits are not iron skarns formed by contact metamorphism as defined by Einaudi et al., (1981) and Meinert et al., (2005) because they lack cogenetic intrusions. Moreover, Li (2012) and $\mathrm{Li}$ et al. (2014) demonstrate different relationships between basaltic injections, skarn and mineralized sequence than those generally observed in intrusion-related iron skarns. Recently, based on detailed works of Hou et al., (2014a) on the Yamansu deposit, Hou et al. (2014b) proposed a new genetic model for the Chinese 
skarn-related iron deposits. This "Submarine Volcanogenic Iron Oxide (SVIO)"model involve: i) facies variation in submarine volcanic rocks from a large central-vent composite volcano, ii). mainly stratiform and sub-horizontal ore bodies at the deposition time; iii) convecting aqueous chloride solution deriving from evolved-magma- fluids mixed with seawater; iv) and consequently, a sub-contemporaneity between volcanism, skarnization and iron mineralization.

However, at Yamansu the initial dip of the stratoïd ore bodies is still questionable as Permian deformation overprints the initial structures involved in the genesis of the deposit and rotates the primary geometry. This constitutes a major pitfall for the recently proposed SVIO model, and points toward the necessity of an integration and understanding of such ore deposits within the structural framework and evolution of the eastern Tianshan orogenic segment. To constrain the initial position of the Yamansu iron deposits, the basalts and massive garnet skarns associated with ore deposition have been sampled for paleomagnetic and AMS studies. Moreover, as the AMS method is sensitive to the magnetic mineral texture (Borradaile and Tarling, 1981; Hrouda, 1982) magnetic fabrics are used to trace deformation events (Cifelli et al., 2004) and/or fluid circulation events in the primary structures (Sizaret et al., 2006a, b). All these data are finally integrated in a genetic model, starting by magmatism associate with metasomatism along a major fault during the late Carboniferous, and its tilting by the dextral strike-slip Permian deformation.

\section{The Yamansu Magnetite Deposit (YMD)}




\subsection{Geological setting}

The Yamansu magnetite ore field is located in the Aqishan-Yamansu arc belt (Fig. 1) that experienced north-verging thrusting and folding during the Carboniferous. This former deformation event is characterized by ductile deformation in the Yamansu Huangshan area and corresponds to a syn-arc thin-skinned tectonic event. (Laurent-Charvet et al., 2002; Charvet et al., 2011). Overprinting these former structures, the Yamansu area is affected by a wide and distributed vertical E-NE-trending right-lateral shear zone (Fig. 2a). Like many major shear zones in eastern Tianshan, the dextral shearing along the Yamansu shear zone (Fig. 2a) was thought to be Permian in age (Shu et al., 1999; Branquet et al., 2012). As a result of the deformation event, the present day geometry of the YMD corresponds to a tilted and deformed monocline that extends E-W and dips south at an average angle of about $60^{\circ}$ (Figs. 2b and 2c).

Close to the deposit, the formation is locally dominated by Early Carboniferous limestone (Baosteel-Company, 1977; XBGMR, 1993), tuff, basalt and arkose with minor lava (Fig. 2a). Basalts have been dated at $344 \pm 16 \mathrm{Ma}$ from a Rb-Sr age isochron with an ${ }^{87} \mathrm{Sr} /{ }^{86} \mathrm{Sr}$ initial value of $0.7055 \pm 0.0001$ (Lu et al., 1995). More recently, Hou et al. (2014 a) dated the basalts at 324.4 $\pm 0.94 \mathrm{Ma}$ (LAICP-MS U-Pb on zircon). The basalt has a geochemical signature between Mid Ocean Ridge Basalt and Island Arc Basalt, indicating a back-arc tectonic setting. Moreover, clinopyroxene 
studies suggest a crystallization temperature of about $1150{ }^{\circ} \mathrm{C}$, suggesting the presence of a shallow magma chamber (4-10km; Hou et al., 2007).

The Yamansu ore field contains at least six tabular ore bodies. Among them, YMD is the largest one in the easternmost part of the ore field (Fig. 2a). The YMD contains a reserve of $32 \mathrm{Mt}$ with an average grade of $51 \% \mathrm{Fe}$ and 20,000 t of $\mathrm{Cu}$ with a mean grade of $0.06 \% \mathrm{Cu}$ (Mao et al., 2005). The ore bodies are spatially associated with a $\sim 50 \mathrm{~m}$ thick stratoid garnet skarn and marble lenses intercalated within Early Carboniferous limestones and basaltic sills (Fig. 2). Basalt and skarn yield coeval ages as the skarn gives a $323.47 \pm 0.95 \mathrm{Ma}$ age (U/Pb on Zircon, Hou et al., 2014a). It is noteworthy that these ages have been debated (see recent comment and reply by Li et al., 2014 and Hou et al., 2014c).

In the walls of the galleries, we observed xenoliths of marbles embedded in the basaltic matrix (Fig. 3). This strongly suggests magmatic stoping and probable carbonate assimilation; basalts at Yamansu being injected sills within limestones rather than surficial lava flows.

To the south of the YMD, a fault branch of the Yamansu shear zone bounds a Permian basin (Fig. 2a). Greywacke beds in the basin trend sub-parallel to the shear zone with a regular southerly dip. Within the Permian basin and in the Yamansu pit, meter-thick steeply-dipping dikes crosscut the skarn, Carboniferous limestone and Permian formations. These dikes have been dated as Permian, coeval with the regional strike-slip shearing (Li et al., 2006).

The occurrence and the common localization of skarn, magnetite ore bodies, 
injected basaltic sills and Permian basin border along the Yamansu shear zone are potentially indicative of a common heritage in this fault system before being reactivated during Permian strike-slip tectonics. This study aims to constrain this heritage.

\subsection{Structure and deformation}

In the Yamansu open pit, there are two dominant groups of brittle faults. The fault plane of the first group is subparallel to the ore bodies and limestone bedding $\left(165^{\circ} \angle\right.$ $49^{\circ}$, in dip direction/dip notation). In the pit, slickensides associated with these fault planes form two distinct sets (Fig. 4b): (1) E-W oriented with a low to moderate westward plunge. The kinematics criteria indicate dextral sense of shear (Fig. 4c); and, (2) SSE oriented with a southward steep plunge, shear criteria showing thrusting (Fig. 4d). No clear crosscutting relationships are observable between the two kinematics.

The second group of faults is mostly NE-SW to NNE-SSW trending (Fig. 4a). The most important of these faults are responsible for decametric offset of ore bodies (Fig 2b). Slickensides and shear criteria are very sparse along this fault family and cartographic offsets indicate both dextral and sinistral relative motion (Fig. 2b).

North of the Yamansu open pit, en echelon tension gashes within conjugate shear bands and pressure-solution cleavage are associated within the Carboniferous limestones (Figs. 4e). All of these markers are vertical and clearly indicate an NW directed horizontal shortening. 
Finally, as already proposed by several authors (Shu et al., 1999; Pirajno, 2010), our structural data at the Yamansu pit scale are consistent with the Permian right-lateral strike-slip and we infer that the Yamansu iron deposit is located within a major Permian shear zone at the eastern Tianshan scale.

\section{Skarn Texture and Paragenesis}

The prograde skarn-related minerals are dominated by andradite and grossularite with minor pyroxene and they are extensively altered by chlorite and epidote. Pyrite, chalcopyrite and borosilicate (i.e. tourmaline and axinite) are observed crosscutting massive magnetite, indicating their later deposition during the retrograde stage. The paragenetic succession for the YMD is given in Figure 5.

The main texture within the massive garnet skarn is a centimetre- to metre-scale banding of alternating coarse-grained garnet-rich ribbons with thin green epidote and chlorite-rich ribbons (Fig. 6a). Within the garnet skarn, basaltic relics occur that vary in size from a few to about $30 \mathrm{~cm}$. They show irregular rounded shapes with gradational wavy boundaries. In some places, far from the massive garnet ribbons and magnetite bodies, the basaltic sill is partially replaced by andradite growing in the groundmass, whereas euhedral/subhedral plagioclase is still present (Fig. 6b).

Massive magnetite bodies are of two types: (i) massive magnetite lobes replacing marble with a reaction front outlined by garnet growth that can be observed under microscope, leading to the integration of garnet within massive magnetite (Fig. 6); 
and, (ii) massive magnetite lenses in the centre of Yamansu open pit with a banding pattern composed of alternating magnetite and garnets ribbons. Grandite veinlets crosscutting massive magnetite suggest that magnetite is deposited late but during the prograde stage (Figs 6d and e, Fig. 5). At a microscopic scale the garnet displays a remarkably complex zoning with: (i) a brown andradite core; (ii) a rim of calcite and magnetite inclusions; and, (iii) a border with anomalous birefringence of andratite-grossular composition (45\% mol grossular) (Figs. 7a, b) that is classical for iron skarn (Einaudi and Burt, 1982).

According to the salinity of the fluid inclusions in calcite (Lu et al., 1996) and the calculated stability limits of stilpnomelane (Miyano and Klein, 1989) that altered the garnet in the YMD, the formation temperature of garnet in the prograde stage was above $500^{\circ} \mathrm{C}$. Fluid inclusions in magnetite and pyrite give homogenization temperatures of $340-330^{\circ} \mathrm{C}$ and $220-150^{\circ} \mathrm{C}$, respectively, with salinities between 12.9 and 2.7 $\mathrm{NaCl}$ equiv (Liu et al., 1996).

\section{Paleomagnetic and Magnetic Fabric Study}

\subsection{Sampling and measurement}

Using a portable gasoline drill, 275 cores from 24 sites were sampled in the Yamansu open pit (Fig. 2b). Solar azimuth was measured systematically for all samples to avoid declination deviations caused possibly by the magnetite-rich basaltic 
sill and magnetite ore bodies. Standard specimens of $2.5 \mathrm{~cm}$ in diameter and $2.2 \mathrm{~cm}$ in height were prepared in the laboratory.

All specimens were measured for the magnetic fabric study. Twenty oriented cores were taken for paleomagnetic study from two of the 24 sites that were space about 900m apart (Sites 06 and 16 in Fig. 2b). The lithology of these cores were classified into six groups i.e, basalt, massive garnet skarn, ore shoot (magnetite), retrograde stage skarn (epidote, chlorite, K-feldspar, tourmaline), marble and Permian dikes. Sites 06 and 16 are composed of "basalt" with disseminated magnetite and massive garnet skarn, respectively.

Magnetic remanence measurements and alternating field (AF) demagnetization were performed with an Agico JR5A spinner magnetometer and an Agico LDA-3 demagnetizer, respectively, in the Institut des Sciences de la Terre d'Orléans, France. All specimens were progressively demagnetized by about 10 steps from 0 to $50 \mathrm{mT}$. Corresponding remanent magnetic directions were calculated by principal component analysis (Kirschvink, 1980) and the average of these directions was calculated using Fisher statistics (Fisher, 1953).

The bulk magnetic susceptibility and AMS were measured with a KLY-3S Kappabridge apparatus. The mean orientations of the three principal ellipsoidal axes of AMS $\left(K_{1}>K_{2}>K_{3}\right)$ for each site were computed with ANISOFT software using Jelinek's statistics (Jelinek, 1981). During the laboratory measurements, some samples showed so high a magnetic susceptibility that they saturated the magnetic instruments. In these cases, the cores were re-cut into cubic specimens of $9 \mathrm{~mm}$ and/or 
$6 \mathrm{~mm}$ in length. As the smaller volume will increase the measurement errors, at least two cubes were taken for each core.

\subsection{Magnetic mineralogy}

In order to identify the magnetic remanence and susceptibility carriers, magnetic hysteresis measurements and thermomagnetic curves were performed. Hysteresis data were acquired at the paleomagnetic laboratory of Institut de Physique du Globe de Paris using a translation inductometer within an electromagnet providing a field of up to $1 \mathrm{~T}$. Thermomagnetic measurements were done in the rock magnetism laboratory of the Orleans University using an AGICO KLY3 Kappabridge-CS3 furnace apparatus.

Hysteresis measurements reveal characteristics of ferromagnetic (sensu lato) minerals in all lithologies (i.e. basalt, massive garnet skarn, ore shoot, retrograde stage skarn and Permian dikes; Figs. 8A and 8B) except in marble (Figs. 8c). High $\mathrm{Hcr} / \mathrm{Hc}$ ratio (3.69-12.2) versus low Mrs/Ms ratio (0.0347-0.14) on a Day plot diagram show the presence of pseudosingle domain magnetite (Fig. 9). The thermomagnetic curves decrease in intensity during heating up to about $350^{\circ} \mathrm{C}$, suggesting the possible presence of maghemite or pyrrhotite. The susceptibility shows a sharp drop down at $580^{\circ} \mathrm{C}$, revealing the Curie temperature of magnetite (Fig. 8d). A Day diagram shows the presence of multidomain magnetites, suggesting that the magnetic fabrics are normal (Fig. 9; Dunlop, 2002). Such results are consistent with our microscopic observations in which magnetite grains are frequently observed with sizes varying 
from $10 \mu \mathrm{m}$ for inclusions to $200 \mu \mathrm{m}$ in massive magnetite bodies.

The hysteresis curve obtained from the marble sample displays diamagnetic characteristics (Fig. 8c). Diamagnetic calcite with low iron content is known to have an inverse fabric i.e. the calcite $\left\langle c>\right.$ axes are parallel to the $\mathrm{K}_{3}$ axis (inverse fabric) as $\mathrm{K}_{1}, \mathrm{~K}_{2}$ and $\mathrm{K}_{3}$ are sorted according to their algebraic values (Rochette 1988; Schmidt et al., 2006; Essalhi et al., 2009). Goniometric analyses on marble confirm that the lower value $\mathrm{K}_{3}$ is parallel to the $\langle\mathrm{c}>$ in the YMD (Fig. 10).

\subsection{Paleomagnetic results}

The progressive AF demagnetization of samples from the basaltic sill and massive garnet skarn reveals two distinct groups of magnetic remanence behaviours (Table 1; Fig. 11)

The first group concerns samples taken mostly in the massive garnet skarn and shows only one magnetic component with a normal polarity that disappears after cleaning with a $15 \mathrm{mT}$ alternate field. The average geographic orientation of the magnetic direction is $\mathrm{Dg}=9.7^{\circ}, \mathrm{Ig}=58.9^{\circ}, \mathrm{kg}=103.2, \alpha_{95 \mathrm{~g}}=5.1^{\circ}$ with $\mathrm{n}=9$ ( $\mathrm{D}=$ declination, $\mathrm{I}=$ inclination, $\mathrm{k}=$ precision parameter of Fisher (1953), $\alpha_{95}=$ radius of cone of $95 \%$ confidence for the site, subscript $g$ indicates geographic coordinates). This direction is close to the dipolar Present Earth's Magnetic Field (PEMF: D $=0^{\circ}$, I $=61^{\circ}$, Fig. 12a). Applying bedding tilt corrections to the average direction gives Ds $=$ $131.4^{\circ}$, Is $=66.1^{\circ}, \mathrm{ks}=103.2$ and $\alpha_{95 \mathrm{~s}}=5.1^{\circ}$ in stratigraphic coordinates (Table 1 and 
Fig. 12b). This result is not comparable with any paleomagnetic direction found in the surrounding areas since the late Paleozoic.

The second group remanence behaviours shows two components. The first is a low-coercivity normal polarity direction similar to the PEMF and cleaned (i.e. removed) by a low AF field up to $7 \mathrm{mT}$. The second component has a higher coercitivity ( 7 to $50 \mathrm{mT}$ ) and an average remanence direction of $\mathrm{Dg}=136.8^{\circ}, \mathrm{Ig}=$ $15.6^{\circ}, \mathrm{kg}=29.9, \alpha_{95 \mathrm{~g}}=10.3^{\circ}$ and $\mathrm{n}=8$ in geographic coordinates (Fig. 13a). After bedding tilt corrections this component reveals a reverse paleomagnetic direction of Ds $=134.1^{\circ}, \mathrm{Is}=-27.9^{\circ}, \mathrm{ks}=29.9$ and $\alpha_{95 \mathrm{~s}}=10.3^{\circ}$ (Table 1 and Fig. 13b). This direction can be related to the late Paleozoic field (see the discussion).

\subsection{Magnetic fabrics}

The results given in Figures 14 and 15 and in Table 2 are presented by lithology and sites. Skarn, magnetite bodies, basalt and samples with retrograde-stage epidote are magnetite rich and, obviously, have a high bulk magnetic susceptibility from $3.10 \times 10^{-2}$ to $6.65 \times 10^{-3}$ S.I. Conversely the Permian dikes displayed relatively low bulk susceptibility from $1.83 \times 10^{-5}$ to $1.2 \times 10^{-4}$ S.I. and the marble samples are diamagnetic.

The majority of the magnetic fabrics are oblate $(\mathrm{T}>0): 17$ sites with positive $\mathrm{T}$ values up to 0.724 and 7 sites has negative T values not below -0.379 (Fig. 14a and Table2). The the degree of anisotropy $\left(\mathrm{P}_{\mathrm{J}}\right)$ is relatively low (11 sites below 1.1) to moderate (Pj maximum value is below 1.3) and it increases with susceptibility (Figs $14 \mathrm{~b}$ and Table 2).

Figure 15 presents for each site the AMS principal axes $\left(\mathrm{K}_{1}, \mathrm{~K}_{2}\right.$ and $\left.\mathrm{K}_{3}\right)$ on an 
equal-area projection. Results of samples taken from basalt, magnetite bodies, skarn and retrograde stages are presented after bedding correction $\left(165^{\circ} \angle 49^{\circ}\right)$, whereas the results from the marble and Permian dikes are presented in geographic coordinates. The characteristics of the magnetic fabrics are described in the following lines:

(1) The three sites of basaltic sill display a relatively horizontal magnetic lineation $\left(\mathrm{K}_{1}\right)$ and a foliation with a low anisotropy degree $\left(\mathrm{P}_{\mathrm{J}}\right.$ values less than 1.2). After bedding corrections, the lineation directions are : $\mathrm{N} 26.6^{\circ} \mathrm{E} 23.6^{\circ}, \mathrm{N} 179.5^{\circ} \mathrm{E} 16.5^{\circ}$, $\mathrm{N} 249^{\circ} \mathrm{E} 2.6^{\circ}$ and the poles of foliation are $\mathrm{N} 150.2^{\circ} \mathrm{E} 51.7^{\circ}, \mathrm{N} 314.2^{\circ} \mathrm{E} 67.1^{\circ}$, $\mathrm{N} 343.9^{\circ} \mathrm{E} 62.4^{\circ}$, for sites $07,09-1$ and 16 , respectively (fig. 15). .

(2) The five sites of massive garnet skarn also show a horizontal magnetic lineation and foliation: after bedding corrections the poles of foliation are the following $\mathrm{N} 118.3^{\circ} \mathrm{E} 76.2^{\circ}, \mathrm{N} 191.3^{\circ} \mathrm{E} 20.4^{\circ}, \mathrm{N} 347.1^{\circ} \mathrm{E} 65.3^{\circ}, \mathrm{N} 155.6^{\circ} \mathrm{E} 79.6^{\circ}, \mathrm{N} 193.9^{\circ} \mathrm{E} 84.9^{\circ}$ (sites $04-2,05-2,13,15-1,15-2$, respectively, fig. 15). The average lineation is well defined with a NE-SW trend (the lineation after bedding corrections are : $\mathrm{N} 213^{\circ} \mathrm{E} 1.1^{\circ}$, $\mathrm{N} 357.4^{\circ} \mathrm{E} 69^{\circ}, \mathrm{N} 213.7^{\circ} \mathrm{E} 17.7^{\circ}, \mathrm{N} 395.5^{\circ} \mathrm{E} 5.2^{\circ}, \mathrm{N} 100.2^{\circ} \mathrm{E} 0.4^{\circ}$, respectively). Two sites reveal high $\mathrm{P}_{\mathrm{J}}$ values (Sites 15-1 and 04-2) and high susceptibility, probably due to their high content of magnetite (details are addressed in Section 5.2). The site 17-1 displays a vertical magnetic foliation after bedding corrections $\mathrm{N} 288.8^{\circ} 7^{\circ}$ with a relatively redressed lineation $\mathrm{N} 166.0^{\circ} 60.9^{\circ}$ ) and the sites 06 and $05-1$ seem ambiguous with an intermediate dip for the foliation $\left(\mathrm{N} 43.3^{\circ} \mathrm{E} 34^{\circ}\right.$ and $\mathrm{N} 216^{\circ} \mathrm{E} 34.4^{\circ}$, respectively) and horizontal lineation $\left(\mathrm{N} 297.1^{\circ} 22.5^{\circ}\right.$ and $\left.\mathrm{N} 118.2^{\circ} 11.1^{\circ}\right)$.

(3) Three of the six sites from the massive magnetite bodies display a horizontal 
magnetic foliation (the pole of foliation after bedding corrections are $\mathrm{N} 355.6^{\circ} \mathrm{E} 78.6^{\circ}$, $\mathrm{N} 350.9^{\circ} \mathrm{E} 75.9^{\circ}, \mathrm{N} 304.8^{\circ} \mathrm{E} 46.9^{\circ}$, for sites $01-1,01-2,03$, respectively). The lineation is oriented NE-SW the measures after bedding corrections gives : $\mathrm{N} 243^{\circ} \mathrm{E} 3.6^{\circ}$, $\mathrm{N} 252.2^{\circ} \mathrm{E} 2.1^{\circ}, \mathrm{N} 211.7^{\circ} \mathrm{E} 2.9^{\circ}$, respectively). The other three sites have $\mathrm{N}-\mathrm{S}$ to NE-SW vertical foliation (The pole of foliation after bedding corrections are $\mathrm{N} 330.1^{\circ} \mathrm{E} 5.3^{\circ}, \mathrm{N} 283.7^{\circ} \mathrm{E} 7^{\circ}, \mathrm{N} 287.6^{\circ} \mathrm{E} 30^{\circ}$ for the sites $\left.02,12-2,17-2\right)$ and the lineations have scattered direction: $\mathrm{N} 60.4^{\circ} \mathrm{E} 1.9^{\circ}, \mathrm{N} 31.9^{\circ} \mathrm{E} 68.7^{\circ}, \mathrm{N} 49.4^{\circ} \mathrm{E} 42.5^{\circ}$ (fig. $15)$.

(4) The sites 08 and 10 sampled in the retrograde stage present a horizontal foliation after bedding corrections $\left(\mathrm{N} 57.2^{\circ} \mathrm{E} 68.8^{\circ}\right.$ and $\mathrm{N} 161.2^{\circ} \mathrm{E} 80.5^{\circ}$, respectively) and a flat lineation $\left(\mathrm{N} 200.7^{\circ} \mathrm{E} 17.4^{\circ}, \mathrm{N} 293.7^{\circ} \mathrm{E} 6.4^{\circ}\right.$, respectively), whereas the site $09-2$ has a rather vertical foliation $\left(\mathrm{N} 7^{\circ} \mathrm{E} 17.9\right)$ and a lineation oriented $\mathrm{N} 263.2^{\circ} \mathrm{E} 36.4^{\circ}$.

(5) The samples drilled in marble show a near vertical $\mathrm{N} 170^{\circ} \mathrm{E}$ magnetic foliation (The pole of foliation with no bedding corrections in this case are $\mathrm{N} 339.5^{\circ} \mathrm{E} 19^{\circ}$ and $\mathrm{N} 350^{\circ} \mathrm{E} 13.3^{\circ}$, sites 9,6 , respectively). The lineation is horizontal with the following orientation: $\mathrm{N} 73.6^{\circ} \mathrm{E} 11.9^{\circ}$ and $\mathrm{N} 80.6^{\circ} \mathrm{E} 2.6^{\circ}$, respectively.

(6) The AMS measured in the Permian dikes show a low degree of anisotropy, a clustered vertical lineation, and variable shape parameters (Table 2). As for samples from Site 04-1, its vertical foliation is dominant and parallel to the dike: the pole of foliation with no bedding correction is $\mathrm{N} 312.6^{\circ} \mathrm{E} 9.3^{\circ}$ with a vertical lineation $\left(\mathrm{N} 187.2^{\circ} \mathrm{E} 74.2^{\circ}\right)$, and for Site 14 , the foliation with a pole oriented $\mathrm{N} 53.2^{\circ} \mathrm{E} 6.9^{\circ}$ differs from the dike orientation as its shape parameter is close to 0 , the lineation is 
vertical oriented $\mathrm{N} 192.7^{\circ} \mathrm{E} 81^{\circ}$.

Most of the magnetic foliations measured in the basalts, magnetite bodies, skarn and retrograde stage facies are horizontal and show no relationship between the degree of anisotropy $\mathrm{P}_{\mathrm{J}}$ and the direction of the magnetic foliation (Table 2).

\section{Discussion}

\subsection{Ore body initial position}

Field observations provide evidence on the tilting of the Carboniferous sedimentary series, however, the initial position of the skarn and magnetite bodies has been poorly constrained so far this work. The high coercitivity remanence components of the measured basalt and skarn samples give well grouped directions. The paleomagnetic fold test cannot be applied to these directions because of the monoclinal bedding, however the untilted magnetic directions (i.e. after bedding correction) are reversed and are aligned with the Kiaman Reverse Superchron directions dated from 312 to 262 Ma (Merrill et al., 1996). These directions are similar also to those obtained from late Paleozoic rocks at $324 \mathrm{Ma}$ in the Tianshan region (e.g. Li et al., 1999). The magnetic remanence isolated from the higher coercive component may be considered therefore as primary. Consequently, the "basalt" likely intruded horizontally into the limestone as a sill before being tilted during later Permian strike-slip faulting. In the same way, the skarnization would have 
occurred before tilting. Though, no dating using paleomagnetic data is proposed in this study because of the small number of samples, the possibility of slightly inclined basalt bedding and the influence of secular variation.

Finally the structural data are coherent and compatible with the transpressional right-lateral strike-slip along the Yamansu shear zone: the horizontal NW shortening is accommodated by coeval dextral and reverse fault planes. In this context, NNE/NE-trending faults might be interpreted as domino (i.e. "bookshelf") faults, but as said above, the antithetic kinematics are not proven. It is noteworthy that this deformation postdates the ore deposition as it is crosscut and offset by the faults.

6.2 Interpretation of magnetic fabrics: deformation vs. magmatic flow and fluid flow

In the "basalt", skarn, magnetite bodies and retrograde assemblage, the susceptibility carrier is multidomain magnetite and the magnetic fabrics are normal (i.e. there is a correspondence between the shapes of the magnetite grain and the ellipsoid susceptibility: the long axis of the grain has the K1 direction and the magnetite foliation is parallel to the grain flattening). After bedding corrections, the horizontal magnetic fabrics of the "basalt" together with their low degree of anisotropy is interpreted to be magmatic, and suggests a horizontal N-S magma flow (i.e. perpendicular to the Yamansu fault) during the sill intrusion. The skarn formation, magnetite bodies and retrograde assemblage show two principal types of magnetic fabrics: a mainly $\mathrm{N}-\mathrm{S}$ oriented vertical foliation and horizontal foliations with a 
frequent NE-SW lineation with a variable degree of anisotropy $\left(\mathrm{P}_{\mathrm{J}}\right)$ that depends on the bulk susceptibility values $(\mathrm{Km})$ (Fig. 13b). Thus $\mathrm{P}_{\mathrm{J}}$ is controlled by the magnetite content within the samples rather than by the deformation. This interpretation is supported also by the absence of a correlation between the variations of the anisotropy degree and the dip of the foliation. Therefore the magnetic fabrics are not related to the deformation. Comparing these fabrics with those measured in basalt could lead to the conclusion that fabrics in the skarn are inherited from the "basalt". However, such a conclusion is not tenable because the magnetite does not have a magmatic origin as iron concentration and bulk susceptibility are both higher in the skarn than in the basalt. The magnetic fabrics measured in those rocks are, therefore, related to hydrothermal magnetite formed during a metasomatic event. In this case it is possible to interpret the magnetic fabric in terms of hydrothermal fluid flow direction. The fabrics carried by minerals with a high susceptibility such as magnetite are related to the shape of the minerals (Stacey and Barnerjee 1974 in Dunlop and Özdemir 1997). It is known that hydrothermal flow influences the shape of the precipitating minerals, i.e. the shape is elongated along the flow direction (Sizaret et al. 2002; Sizaret et al., 2006a, Essalhi et al., 2009 ). In such conditions, we propose that magnetite in the Yamansu deposit has recorded the metasomatic flow direction. Horizontal fabrics with NE-SW lineation suggest the metasomatic flow was parallel to the boundaries of the sill and oblique to the Yamansu fault. The N-S oriented vertical foliations with vertical lineation (such as Sites 17-1 in the garnet skarn and 12-2 in the magnetite ore body) are interpreted to be in N-S to NE-SW vertical fractures carrying hydrothermal 
flows. The study of basaltic and metasomatic flow implies both the pre-existence of a fault that channelized magma and hydrothermal fluids before the deformation events.

The susceptibility carrier in marble is calcite. Its fabrics are controlled by the orientation of the calcite $<c>$ axes that are parallel to $K_{3}$ axis (inverse fabric; Fig. 10). The $340-350^{\circ}$ orientation of the $\langle\mathrm{c}>$ axis is interpreted to be the result of dextral shearing. Previous studies on natural samples show that low temperature $\left(<300^{\circ} \mathrm{C}\right)$ shearing may produce a rotation of the $\langle\mathrm{c}\rangle$ axis in an opposite sense to the shearing as the twining of the calcite tends to be parallel to the main stress $\sigma_{1}$ and to the $\langle\mathrm{c}\rangle$ axis (e.g. Turner et al., 1954; Wenk et al., 1987; Nicol 1997).

Samples taken in the dykes show a vertical lineation that is interpreted to record a vertical magma flow pattern. Previous studies have shown that mafic dykes mostly preserve a vertical $\mathrm{K}_{1}$ orientation, indicating vertical magmatic flow (e.g. Craddock et al., 2008). Studies reveal that the vertical- $\mathrm{K}_{1}$-type dykes were formed in an extension and fast upward flow environment (Callot and Guichet, 2003; Cañón-Tapia and Herrero-Bervera, 2009), however imbrications have been observed in some cases and could explain that the foliation is not parallel to the dike (site 14) (Tarling and Hrouda, 1993).

\subsection{Model and conclusions}

In their general reviews on world skarn deposits, Einaudi et al., (1981) and Meinert et al., (2005) proposed a continuum between metamorphic hornfels and 
metasomatic skarn. In the Yamansu skarn, even if the fluids produced by the basalt would have contributed to deuteric alteration, the large amount of iron compared to basalt must have involved a huge contribution of metasomatism with a large fluid flow to provide the necessary chemical fluxes. As discussed above, the pre-existing fault probably channelized deep-sourced, rapidly ascending fluids (Fig. 16). This paleomagnetic study shows that the basaltic sill and the skarn deposit were tilted during Permian dextral shear.

These results are in agreement with the SVIO model proposed by Hou et al., (2014b) supporting the hypothesis of stratoid basaltic bodies being metasomatised soon after emplacement from a shallow magma chamber by seawater circulation through pre-existing faults. However, field observations show the presence of magmatic stoping and the absence of pillows to strongly support sill emplacement rather than submarine basaltic flow. The textural observation supports the idea of a progressive replacement of the protolith by a garnet skarn under the relatively low pressure necessary for andradite and grossular nucleation and growth (Hariya et al., 1978). Moreover, our paragenetic study establishes the magnetite stage during the prograde stage with a mineralizing peak at the end, which is uncommon. Such a characteristic could be linked to the shallow position of skarn and could be the one of the characteristics of SVIO model.

In summary, the formation of the YMD can be described in four steps as follow:

1. Deformation of the host Paleozoic formations by north-verging thrusting and folding that was accompanied by calc-alkaline magmatism (Fig. 16a) (Wang et al., 
2010; Charvet et al., 2011; Wu et al., 2006). Locally at Yamansu in back-arc environment, basaltic sills are injected into flat-lying limestone along a pre-existing vertical fault (Fig. 16b) Metasomatic fluid was channelized along the same fault and flowed parallel to the sill into the limestone in a N-S direction to produce the garnet skarn and the magnetite deposit in a submarine volcanic environnment (Fig. 16b).

2. Early Permian dextral transtensive strike-slip along the Yamansu shear zone responsible for tectonic subsidence in pull apart area were small Permian basin formed (Fig 16c). Note that mafic/ultramafic magmatism occurred at this time along other major Tianshan shear zones (e.g. Branquet et al., 2009).

3. Finally, according to our structural data, Late Permian dextral transpressive strike-slip tilted the formations into a positive flower structure that was responsible for the present attitude of the basalt, skarn and ore shoots (Fig. 16d).

According to our paleomagnetic study, the emplacement of the basaltic sill probably occurred in Late Carboniferous before Permian deformation. Finally, this is the first study to use magnetic fabrics to identify the primary flow direction during the genesis of a skarn-related deposit. We posit that the AMS is an efficient tool for determining the fluid flow circulation and front migration in metasomatic processes.

\section{Acknowledgements}

We specially thank Baosteel Company for providing access to their mine and unpublished documents. The first author benefits from a scholarship grant from the 
French Ministry of Education and Research. This study was financially supported by the National 973 Project (2007CB411301), Geological Survey Project (1212011140056) and NNSFC (40603008, 40672040) of China. Thanks a lot to Dr D.T.A Symons, Dr J. Žák, and Dr Santosh associate editor who have reviewed and improved the presented manuscript. 


\section{REFERENCES}

Baosteel-Company 1977. geological report.Borradaile, G.J., Tarling D.H., 1981. The influence of deformation mechanisms on magnetic fabrics in weakly deformed rocks. Tectonophysics 77, 151-168.

Branquet, Y., Gumiaux, C., Sizaret, S., Barbanson, L., Wang, B., Cluzel, D., Li, G., Launay, A.D., 2012. Synkinematic mafic/ultramafic sheeted intrusions. emplacement mechanism and strain restoration of the Permian Huangshan Ni-Cu ore belt (Eastern Tianshan, NW China). Journal of Asian Earth Sciences $56,240-257$.

Callot, J. and Guichet, X., 2003. Rock texture and magnetic lineation in dykes. a simple analytical model. Tectonophysics 366, 207-222.

Cañón-Tapia, E., Herrero-Bervera, E., 2009. Sampling strategies and the anisotropy of magnetic susceptibility of dykes. Tectonophysics 466, 3-17.

Charvet, J., Shu, L., Laurent-Charvet, S., 2007. Paleozoic structural and geodynamic evolution of eastern Tianshan (NW China). welding of the Tarim and Junggar plates. Episodes 30, 162-186

Charvet, J., Shu, L., Laurent-Charvet, S., Wang, B., Faure, M., Cluzel, D., Chen, Y., De Jong, K., 2011. Palaeozoic tectonic evolution of the Tianshan belt, NW China. Science China Earth Sciences 54, 166-184.

Cifelli, F., Rossetti, F., Mattei, M., Hirt, A.M., Funiciello, R., Tortorici, L., 2004. An AMS, structural and paleomagnetic study of quaternary deformation in eastern Sicily. Journal of Structural Geology 26, 29-46. 
Craddock, J.P., Kennedy, B.C., Cook, A.L., Pawlisch, M.S., Johnston, S.T., Jackson, M., 2008. Anisotropy of magnetic susceptibility studies in Tertiary ridge-parallel dykes (Iceland), Tertiary margin-normal Aishihik dykes (Yukon), and Proterozoic Kenora-Kabetogama composite dykes (Minnesota and Ontario). Tectonophysics 448, 115-124.

Dunlop, D.J., Özdemir, Ö., 1997. Rock magnetism. fundamentals and frontiers. Cambridge University Press, New York 595 p.

Dunlop, D.J., 2002. Theory and application of the Day plot (Mrs/Ms versus Hcr/Hc) 1. Theoretical curves and tests using titanomagnetite data. Journal of Geophysical Research. 107, 2056, I0.1029/2001JB000486.

Einaudi, M.T., Meinert, L.D., Newberry, R.J., 1981. Skarn deposits. Econmic Geology $75^{\text {th }}$ Anniversary Volume, 317-391.

Einaudi, M.T., Burt, D.M., 1982. A special issue devoted to skarn deposits, introduction - terminologie, classification, and composition of skarn deposits. Econmic Geology 77, 745-754.

Essalhi, M., Sizaret, S., Barbanson, L., Chen, Y., Branquet, Y., Panis, D., Camps, P., Rochette, P., Canals, A., 2009. Track of fluid paleocirculation in dolomite host rock at regional scale by the Anisotropy of Magnetic Susceptibility (AMS). An example from Aptian carbonates of La Florida, Northern Spain. Earth and Planetary Science Letters 277, 501-513.

Fisher, R., 1953. Dispersion on a Sphere. Proceedings of the Royal Society of London. Series A. Mathematical and Physical Sciences 217, 295-305. 
Gu, L., Zhang, Z., Wu, C., Wang, Y., Tang, J., Wang, C., Xi, A., Zheng, Y., 2006. Some problems on granites and vertical growth of the continental crust in the eastern Tianshan Mountains, NW China. Acta Petrologica Sinca 22, 1103-1120.

Han, C., Xiao, W., Bin, C., Mao, Q., Zhang, J., Ao, S., 2006. Major Types and Characteristics of Late Paleozoic Copper Deposits in North Xinjiang, Northwest China. Acta Geologica Sinica 80, 74-89 (in Chinese with English abstract).

Hariza, Y., Kimura, M., 1978. Optical anomaly garnet and its stability field at high pressures and temperatures, Journal of the faculty of sciences, Hokkaido University 18, 611-624.

Hou, G., Tang, H., Liu, C., 2006. Geochemical characteristics of the Late Paleozoic Volcanics in Jueluotage tectonic belt. eastern Tianshan and its implication. Acta Geologica Sinica 22, 1167-1177 (in Chinese with English abstract).

Hou, G., Tang, H., Liu, C., 2007. Study on the mineralogy of volcanics of the Yamansu group in the Jueluotage tectonic belt, East Tianshan. Acta Mis en forme : Anglais (États Unis)
Mis en forme : Anglais (États Unis) Mis en forme : Espagnol (International) Mineralogica Sinica 27, 189-194.

Hou, T., Zhang, Z., Santosh, M., Encarnacion, J., Zhu, J., Luo, W., 2014a. Geochronology and geochemistry of submarine volcanic rocks in the Yamansu iron deposit, Eastern Tianshan Mountains, NW China: Constraints on metallogenesis. Ore Geology Reviews 56, 487-502.

Hou, T., Zhang, Z., Pirajno, F., Santosh, M., Encarnacion, Liu, J., Zhao, Z., Zhang, L., 
2014b. Geology, tectonic settings and iron ore metallogenesis associated with submarine volcanism in China: An overview. Ore Geology Reviews 57, 498-517.

Hou, T., Zhang, Z., Santosh, M., Encarnacion J., Zhua J., Luo, W., 2014c. Reply to the Mis en forme : Anglais (États Unis) comment on "Geochronology and geochemistry of submarine volcanic rocks in the Yamansu iron deposit, Eastern Tianshan Mountains, NW China: Constraints on the metallogenesis" by Hou et al. Ore Geology Review, In press.

Hrouda, F., 1982. Magnetic anisotropy of rocks and its application in geology and geophysics. Surveys in Geophysics 5, 37-82.

Jelinek, V., 1981. Characterization of the magnetic fabric of rocks. Tectonophysics, 79, 63-67.

Kirschvink, J.L., 1980. The least-squares line and plane and the analysis of palaeomagnetic data. Geophysical Journal of the Royal Astronomical Society $62,699-718$.

Laurent-Charvet, S., Charvet, J., Shu, L., Ma, R., Lu, H., 2002. Palaeozoic late collisional strike-slip deformations in Tianshan and Altay, Eastern Xinjiang, NW China . Terra Nova 14, 249-256.

Li, J., 2004. Late Neoproterozoic and Paleozoic tectonic framework and evolution of Eastern Xinjiang, NW China. Geological Review 50, 304-322.

Li, J., Song, B., Wang, K., Li, Y., Sun, G., Qi, D., 2006. Permian mafic-ultramafic complexes on the southern margin of the Tu-Ha basin, East Tianshan 
Mountains. Geological records of vertical crustal growth in Central Asia. Acta Geologica Sinica 27, 424-446 (in Chinese with English abstract).

Li, G., 2012. Iron Ore Deposits in the Eastern Tianshan Orogenic Belt (China):the Magnetite-Skarn-Magmatism Association. Unpublished Ph.D. thesis, Orleans, France, Université d'Orléans 356 p.

Li, G., Wu, C., Branquet, Y., 2014. Comment on "Geochronology and geochemistry of $\underline{\text { submarine volcanic rocks in the Yamansu iron deposit, Eastern Tianshan }}$ Mountains, NW China: Constraints on the metallogenesis" by Tong Hou, Zhaochong Zhang, M. Santosh, John Encarnacion, Jiang Zhu, Wenjuan Luo [Ore Geology Review, 56(2014):487-502]. Ore Geology review, in press. Li, Mis en forme : Anglais (États Unis) Y., Sun, D., Zheng, J., 1999. Paleomagnetic study and tectonic evolution of Xinjiang and its neighboring regions. Xinjiang Geology 17, 192-235.

Liu, D.Q., Tang, Y.L., Zhou, R.H., 1996. Metallogenic series types of deposits in Xinjiang. Mineral Deposits 15, 207-215.

Lu, D., Ji, J., Lu, R., Tao, H., 1995. Geochemical characteristics and metallogeny of the Yamansu iron deposit, Xinjiang (in Chinese). Northwestern Geology 16, $15-19$.

Lu, D., Ji, J., Lu, R., Tao, H., 1996. Geochemical characteristics of the rare earth Mis en forme : Anglais (États Unis) elements of the Yamansu iron deposit. Journal of Xi'an college of geology 18, 12-16 (in Chinese with English abstract).

Ma, R.S., Shu, L.S., Sun, J.Q., 1997. Tectonic evolution and mineralization of Eastern Tianshan. Beijing, Geological Publishing House. 
Mao, J., Goldfarb, R., Wang, Y., Hart, C., Wang, Z., Yang, J., 2005. Late Paleozoic base and precious metal deposits, East Tianshan, Xinjiang, China. Characteristics and geodynamic setting. Episodes 28, 23-36.

Mao, J., Xie, G., Duan, C., Pirajno, F., Ishiyama, D., Chen, Y., 2011. A tectono-genetic model for porphyry-skarn-stratabound $\mathrm{Cu}-\mathrm{Au}-\mathrm{Mo}-\mathrm{Fe}$ and magnetite-apatite deposits along the Middle-Lower Yangtze River Valley, Eastern China. Ore Geology Reviews 43, 294-314.

Meinert, L., Dipple, G., Nicolescu, S., 2005. World skarn deposits. Economic Geology $100^{\text {th }}$ anniversary volume $299-336$.

Merrill, R.T., McElhinny, M.W., McFadden, P.L., 1996. The Magnetic Field of the Earth. Paleomagnetism, the Core, and the Deep Mantle. International Geophyics series 63, 531

Miyano, T., Klein, C., 1989. Phase equilibria in the system $\mathrm{K}_{2} \mathrm{O}-\mathrm{FeO}-\mathrm{MgO}-\mathrm{Al}_{2} \mathrm{O}_{3}-\mathrm{SiO}_{2}-\mathrm{H}_{2} \mathrm{O}-\mathrm{CO}_{2}$ and the stability limit of stilpnomelane in metamorphosed Precambrian iron-formations. Contribution to Mineralogy and Petrography 102, 478-491.

Nicol N., 1997. Structural study of the $\mathrm{Zn}-\mathrm{Pb}$ mineralzations of the paleozoic of the Pierrefitte dome (Hautes Pyrenee)-Texture goniometry applied to transparent and opaque minerals. unpublished Ph.D. thesis, Orleans, France, Université d'Orléans 328 p.

Pirajno, F., Luo, Z., Liu, S., Dong, L., 1997. Gold Deposits in the Eastern Tian Shan, Northwestern China. International Geology Review 39, 891-904. 
Pirajno, F., 2010. Intracontinental strike-slip faults, associated magmatism, mineral systems and mantle dynamics. examples from NW China and Altay-Sayan (Siberia). Journal of Geodynamics 50, 325-346.

Rochette, P., 1988. Inverse magnetic fabric in carbonate-bearing rocks. Earth and Planetary Science Letters 90, 229-237.

Schmidt, V., Günther, D., Hirt, A.M., 2006. Magnetic anisotropy of calcite at room-temperature. Tectonophysics 418, 63-73.

Shu, L., Charvet, J., Guo, L., Lu, H., Charvet, L., 1999. A Large-Scale Palaeozoic Dextral Ductile Strike-Slip Zone:the Aqqikkudug-Weiya Zone along the Northern Margin of the Central Tianshan Belt,Xinjiang,NW China. Acta Geologica Sinica 73, p.148-162 (in Chinese with English abstract).

Sizaret, S., Chen, Y., Barbanson, L., Henry, B., Camps, P., Marcoux, E., $2006 a$. Crystallization in flow - I. Palaeocirculation track by texture analysis and magnetic fabrics. Geophysical Journal International 167, 605-612.

Sizaret, S., Fedioun, I., Barbanson, L., Chen, Y., 2006b. Crystallization in flow - II. Modelling crystal growth kinetics controlled by boundary layer thickness. Geophysical Journal International 167, 1027-1034.

Tarling, D.H., Hrouda, F., 1993. The magnetic anisotropy of rocks, Chapman and Hall, 217.

Turner, F.J., Griggs, D.T., Heard, H., 1954. Experimental deformation of calcite crystals. Geological Society of American Bulletin 65, 883-934.

Wang, B., Chen, Y., Zhan, S., Shu, L., Faure, M., Cluzel, D., Charvet, J., 
Laurent-Charvet, S., 2007. Primary Carboniferous and Permian paleomagnetic results from the Yili Block (NW China) and their implications on the geodynamic evolution of Chinese Tianshan Belt. Earth and Planetary Science Letters 263, 288-308.

Wang, B., Cluzel, D., Shu, L., Faure, M., Charvet, J., Chen, Y., Meffre, S., de Jong, K., 2009. Evolution of calc-alkaline to alkaline magmatism through Carboniferous convergence to Permian transcurrent tectonics, western Chinese Tianshan. International Journal of Earth Sciences 98, 1275-1298.

Wang B., Cluzel D., Jahn B.M., Shu L.,Chen Y., Zhai Y., Branquet Y., Barbanson L., Sizaret S., 2014. Late paleozoic pre- and syn-kinematic plutons of the Kanguer-Huangshan shear zone inference on the tectonic evolution of the eastern chinese north Tianshan. American Journal of Science. 314, 43-79.

Wang, Q., Shu, L., Charvet, J., 2010. Understanding and study perspectives on tectonic evolution and crustal structure of the Paleozoic Chinese Tianshan. Episodes 33, 242-266.

Wang, Y., Li, J., Sun, G., 2008. Postcollisional eastward extrusion and tectonic exhumation along the eastern Tianshan Orogen, Central Asia. constraints from dextral strike-slip motion and ${ }^{40} \mathrm{Ar}-{ }^{39} \mathrm{Ar}$ geochronological evidence. Journal of Geology 116, 599-618.

Wang, Y., Wang, J., Wang, L., Long, L., 2008. Metallogenic Series Related to Permian Mafic Complex in North Xinjiang. Post-collisional Stage or Mantle Plume Result? . Acta Geologica Sinica English Edition 82, 788-795. 
Wang, Y.T., Mao, J., Bierlein, F.P., Mao, J.W., Chen, W., Yang, J.M., Wang, Z.L., Yang, F.Q., 2005. Strike-slip fault controls on mineralization in the Kanggurtag gold belt in the Eastern Tianshan, Xinjiang, NW China. Mineral Deposit Research. Meeting the Global Challenge, Springer Berlin Heidelberg, 1347-1349.

Wenk, H.R., Takeshita, T., Bechler, E., Erskine, B.G., Matthies, S., 1987. Pure shear and simple shear calcite textures. Comparison of experimental, theoretical and natural data. Journal of Structural Geology 9; 731-745.

Wu, C., Zhang, Z., Zaw, K., Della-Pasque, F., Tang, J., Zheng, Y., Wang, C., San, J., 2006. Geochronology, geochemistry and tectonic significances of the Hongyuntan granitoids in the Qoaag area Eastern Tianshan. Acta Petrologica Sinica 22, 1121-1134.

XBGMR, 1993. Xinjiang Bureau of Geology and Mineral Resources:Regional Geology of Xinjiang Uygur Autonomous Region (in Chinese with English abstract). Beijing, Geological Publishing House.

Zhang, L., Ji, J., Li, H., Shen, Y., 2000. Geochemical characteristics and source of two-type oreforming fluids in Kanggultage gold ore belt, east Tianshan. Acta Petrologica Sinica 16, 535-541.

Zhang, L., Qin, K., Xiao, W., 2008. Multiple mineralization events in the eastern Tianshan district, NW China. Isotopic geochronology and geological significance. Journal of Asian Earth Sciences 32, 236-246.

Zhang, L., Qin, K., Ying, J., Xia, B., Shu, J., 2004. The relationship between ore 
forming processes and adakitic rock in Tuwu-Yandong porphyry copper metallogenic belt, eastern Tianshan mountains. Acta Petrologica Sinica 20, 259-268.

Zhang, Z., Gu, L., Wu, C., Li, W., Xi, A., Wang, S., 2005. Zircon SHRIMP Dating for the Weiya Pluton, Eastern Tianshan. Its Geological Implications. Acta Geologica Sinica English edition 79, 481-490.

Zijderveld, J.D.A., 1967. The natural remanent magnetization of the Exeter Volcanic Traps (Permian, Europe). Tectonophysics 4, 121-153

Zou, G., Liang, G., Chen, J., Zheng, Y., Gao, J., Xing, D., Li, S., 2006. Late paleozoic tectonic framword and evolution in the Jiabaishan area, Qoltag, eastern Tianshan, Northwest China. Geological Bulletin of China 25, 48-57. 


\section{FIGURE CAPTIONS}

Fig. 1. Simplified location map showing for the Yamansu iron skarn deposit and the main tectonic units of eastern Tianshan (modified from Li (2004) and Gu et al., (2006)).

FIG. 2. Maps and cross section showing the Yamansu magnetite deposit (YMD). (a) geological map of Yamansu ore field (C1YFS: Lower Carboniferous Yamansu upper Formation, C1YFI: Lower Carboniferous Yamansu lower Formation, C2: Upper Carboniferous, P1: Lower Permian); (b) geological map of the Yamansu pit; the sample names and positions used for AMS and paleomagnetic study are the pink circles with numbers inside; (c) cross section of the Yamansu deposit showing the development of a massive garnet skarn above the stratose magnetite ore body. Note the presence of basaltic relics within the garnet skarn.

Fig. 3. Marble fragments within the strongly altered basaltic sill, suggesting mafic magmatic stoping and potential carbonate assimilation. Reddish ribbons consist in K-feldspar from potassium metasomatism.

Fig. 4. Schmidt equal-area projection plots in the lower hemisphere of (a) poles of fault planes, 301 measurements, and (b) slickensides, 350 measurements; (c) Sigma-type calcite porphyroclast indicating dextral sense of shear; (d) pull-apart filled 
with calcite indicating a reverse sense of shear; (e) NW-SE compressive horizontal shortening attested from associated en echelon tension gashes, conjugated shear bands and pressure-solution cleavage in limestones north of the Yamansu pit.

Fig. 5. Paragenetic sequence for the Yamansu iron skarn.

Fig. 6. Texture and mineralogy of the prograde and massive magnetite stages (modified from Li et al., 2014). (a) Relics of "basalt" (emphasized by dotted yellow lines) in massive reddish garnet skarn. (b) "Basalt" with plagioclase (in white) altered by andradite (in pink). Groundmass and disseminated magnetite are in black; (c) Front developed along the contact between magnetite and marble, where garnet is developed; transmitted plane polarised light. (d) Grandite vein cross-cutting massive magnetite. (e) Rhythmic banding of garnet (reddish) and magnetite (black).

Fig. 7. (a) Electron microprobe analyses showing the 573 compositional variations of garnet from andradite core to grandite border (Cameca SX50 electron microprobe hosted at BRGM equipped with four wavelength dispersion spectrometers WDS). (b) Euhedral garnet from the massive garnet skarn: left and right in transmitted and reflected polarised light, respectively, mgt for magnetite.

Fig. 8. Magnetic hysteresis loops for: (a) basalt, (b) massive garnet skarn (Loop without the contribution of paramagnetic s.s. components, up right: bulk data) and (c) 
marble. (d) Thermo-susceptibility curve for massive garnet skarn. The rapid decrease of magnetic susceptibility in (d) at about $580^{\circ} \mathrm{C}$ indicates the presence of magnetite. Solid (dotted) lines are the heating (cooling) curves.

Fig. 9. Day plot diagram as the ratio of saturation remanence to saturation magnetization $\mathrm{Mrs} / \mathrm{Ms}$ against the ratio of remanent coercive force to ordinary coercive force, modified by (Dunlop, 2002).

Fig. 10. Analysis of the marble texture where the stereogram shows the lattice preferred orientation of the $(00012)$ pole plane, i.e. the calcite $\langle c\rangle$ axis. The colour levels indicate the diffracted X-ray intensities (purple: low and red: high). The anisotropy of magnetic susceptibility (AMS) measures are represented by a square ( $\mathrm{K}_{1}$ magnetic lineation), triangle $\left(\mathrm{K}_{2}\right)$ and circles $\left(\mathrm{K}_{3}\right.$ pole of magnetic foliation).

Fig. 11. Paleomagnetic measurement results from the Yamansu skarn deposit. Orthogonal projection of sample progressive AF demagnetization (Zijderveld, 1967) in geographic and stratigraphic coordinates. White and black circles represent vertical and horizontal planes, respectively. Numbers adjacent to data points indicate peak demagnetizing field in $\mathrm{mT}$.

Fig. 12. Equal-area stereoplots for the weaker viscous remanence that is close to the present Earth's field direction. 
Fig. 13. Equal-area stereoplots for "hard" remanence components. White (black) circles represent reversed (normal) polarities of the mean direction. The left and right show the direction in geographic coordinates and stratigraphic corrected coordinates, respectively.

Fig. 14. AMS scalar parameters for sites grouped by lithologies. (a): T shape parameter vs $\mathrm{P}_{\mathrm{J}}$ corrected anisotropy degree; and; (b) $\mathrm{P}_{\mathrm{J}}$ corrected degree of anisotropy vs. Km, mean bulk magnetic susceptibility in SI.g ${ }^{-1}$.

Fig. 15. AMS results presented in equal-area projections. Squares, triangle and circles stand for $\mathrm{K}_{1}$ (magnetic lineation), $\mathrm{K}_{2}$ and $\mathrm{K}_{3}$ (pole of magnetic foliation), respectively. Confidence ellipses at $95 \%$ level are drawn around site-mean direction. All sites are tilt-corrected coordinates except the sites of dyke and marble. Tilt correction is based on stratification plane marked by the ripple marks in limestone $\left(165^{\circ} \angle 49^{\circ}\right) . \mathrm{P}_{\mathrm{J}}$ values are indicated in red and orange lines in stereoplots give the magnetic foliation.

Fig. 16. Metallogenic model of the Yamansu iron deposit 


\section{TABLE CAPTIONS}

\section{Table 1}

Paleomagnetic measurement results from Yamansu magnetite deposit.

\section{Table 2}

AMS statistic results and associated parameters 


\section{TABLES}

Table 1

Paleomagnetic measurement results from the Yamansu magnetite deposit.

\begin{tabular}{llllllll}
\hline & $\mathrm{N}$ & $\mathrm{Dg}$ & $\mathrm{Ig}$ & $\mathrm{Ds}$ & $\mathrm{Is}$ & $\mathrm{ks}$ & $\mathrm{a} 95$ \\
\hline $\begin{array}{l}\text { Lower coercivity } \\
\text { viscous remanence }\end{array}$ & $\begin{array}{l}9(2 \text { basalt }+7 \\
\text { garnet skarn })\end{array}$ & $9.7^{\circ}$ & $58.9^{\circ}$ & $131.4^{\circ}$ & $66.1^{\circ}$ & 103.2 & $5.1^{\circ}$ \\
& & & & & & \\
$\begin{array}{l}\text { High coercivity } \\
\text { stable remanence }\end{array}$ & $\begin{array}{l}8 \text { (3 basalt }+5 \\
\text { garnet skarn })\end{array}$ & $136.8^{\circ}$ & $15.6^{\circ}$ & $134.1^{\circ}$ & $-27.9^{\circ}$ & 29.9 & 10.3
\end{tabular}

Note: the tilt correction is based on the ripple plane attitude $\left(165^{\circ} \angle 49^{\circ}\right)$ of the limestone. Paleomagnetic samples are from Sites 06 and 16 of basaltic sill and massive garnet, respectively. $\mathrm{N}$ : sample number, Dg: geographic declination, Ig: geographic inclination, Ds: stratigraphic declination, Is: stratigraphic inclination, $\alpha 95$ statistic confidence at 95\% level, ks: magnetic intensity 
Table 2

AMS statistical results and associated parameters

\begin{tabular}{|c|c|c|c|c|c|c|c|c|c|c|c|c|c|}
\hline \multirow[b]{2}{*}{ Site } & \multirow[b]{2}{*}{ Litho } & \multirow[b]{2}{*}{$\mathrm{n}$} & \multicolumn{4}{|c|}{$\mathrm{K}_{1}$} & \multicolumn{4}{|c|}{$\mathrm{K}_{3}$} & \multirow[b]{2}{*}{$\mathrm{P}_{\mathrm{J}}$} & \multirow[b]{2}{*}{$\mathrm{T}$} & \multirow{2}{*}{$\begin{array}{c}\mathrm{Km} \\
\left(\mathrm{SI}^{*} \mathrm{~g}^{-1}\right)\end{array}$} \\
\hline & & & $\mathrm{D}$ & I & $a_{95 \max }$ & $\mathrm{a}_{95 \min }$ & $\mathrm{D}$ & I & $\begin{array}{l}\mathrm{a}_{95} \\
\text { max }\end{array}$ & $a_{95 \min }$ & & & \\
\hline $01-1$ & mgt & 15 & 250.9 & 11.2 & 50.5 & 14.1 & 347.4 & 29.8 & 31.7 & 11.4 & 1.180 & 0.158 & $1.62 \mathrm{E}-02$ \\
\hline $01-2$ & mgt & 18 & 254.8 & 3.5 & 37.4 & 7.7 & 346.6 & 27 & 31.1 & 8.3 & 1.081 & 0.363 & $3.10 \mathrm{E}-02$ \\
\hline 02 & $\mathrm{mgt}$ & 8 & 243.9 & 9.7 & 31.2 & 8.5 & 145.1 & 41.8 & 19.9 & 11.9 & 1.276 & 0.504 & $6.65 \mathrm{E}-03$ \\
\hline 03 & $\mathrm{mgt}$ & 17 & 225.5 & 33.4 & 52.6 & 19.3 & 318.7 & 4.9 & 23.5 & 12.3 & 1.128 & 0.204 & $1.18 \mathrm{E}-02$ \\
\hline $04-1$ & dyke & 5 & 187.2 & 74.2 & 15.5 & 4.3 & 312.6 & 9.3 & 17 & 2.3 & 1.032 & 0.724 & $1.83 \mathrm{E}-05$ \\
\hline $04-2$ & $\begin{array}{l}\text { basalt } \\
+ \text { grt }\end{array}$ & 32 & 225.3 & 31.2 & 17 & 12.2 & 0.5 & 49.5 & 37.8 & 12.4 & 1.535 & 0.063 & $2.21 \mathrm{E}-02$ \\
\hline $05-1$ & grt & 7 & 97.4 & 39.3 & 15.1 & 8.4 & 262.6 & 49.7 & 12.1 & 5.5 & 1.005 & 0.292 & $5.03 \mathrm{E}-05$ \\
\hline $05-2$ & $\begin{array}{l}\text { basalt } \\
+ \text { grt }\end{array}$ & 15 & 220.2 & 59.6 & 12.2 & 4.8 & 349.7 & 20.4 & 8.2 & 3.4 & 1.012 & 0.222 & $2.22 \mathrm{E}-05$ \\
\hline 06 & grt & 8 & 120.4 & 12.5 & 10 & 5.2 & 29.9 & 2.2 & 13.8 & 5.3 & 1.014 & -0.379 & $1.33 \mathrm{E}-04$ \\
\hline 07 & basalt & 10 & 204 & 14.7 & 31.7 & 10.6 & 23.5 & 75.3 & 42.4 & 20 & 1.130 & 0.201 & $1.00 \mathrm{E}-03$ \\
\hline 08 & rss & 10 & 228.1 & 51.3 & 9.9 & 2.2 & 8.9 & 31.9 & 30.8 & 3.3 & 1.017 & -0.150 & $2.33 \mathrm{E}-05$ \\
\hline $09-1$ & basalt & 5 & 196.4 & 62.5 & 18.3 & 9.5 & 332.7 & 20.6 & 53.3 & 10.2 & 1.012 & 0.078 & $1.70 \mathrm{E}-05$ \\
\hline $09-2$ & rss & 5 & 288.3 & 17.6 & 25 & 9.4 & 188.7 & 27.7 & 30 & 6 & 1.002 & -0.194 & $2.90 \mathrm{E}-05$ \\
\hline 10 & rss & 7 & 107.4 & 23.3 & 20.2 & 4.6 & 346 & 50.5 & 17.6 & 6.7 & 1.119 & 0.571 & $8.54 \mathrm{E}-04$ \\
\hline 11 & marble & 9 & 73.6 & 11.9 & 8.8 & 4.2 & 339.5 & 19 & 7.5 & 3.4 & 1.130 & -0.216 & $-2.38 \mathrm{E}-06$ \\
\hline $12-1$ & marble & 6 & 80.6 & 2.6 & 14.4 & 6.2 & 350 & 13.3 & 14.3 & 11.1 & 1.591 & 0.352 & $-1.63 \mathrm{E}-07$ \\
\hline $12-2$ & mgt & 16 & 2 & 25.1 & 14.2 & 8.9 & 99.7 & 16 & 12.1 & 9 & 1.141 & -0.054 & $3.54 \mathrm{E}-02$ \\
\hline 13 & grt & 11 & 240.4 & 42.4 & 25.7 & 19.5 & 345.9 & 16.3 & 27.8 & 19.1 & 1.161 & 0.123 & $1.97 \mathrm{E}-02$ \\
\hline 14 & dyke & 7 & 192.7 & 81 & 10.7 & 5.8 & 53.2 & 6.9 & 16.2 & 5.7 & 1.025 & 0.002 & $1.20 \mathrm{E}-04$ \\
\hline $15-1$ & grt & 9 & 222.8 & 24.7 & 12.7 & 12.4 & 347.7 & 51.2 & 17.3 & 10.2 & 1.229 & 0.388 & $1.16 \mathrm{E}-02$ \\
\hline $15-2$ & grt & 21 & 91.9 & 19 & 18.2 & 14.5 & 341.5 & 45.4 & 25.8 & 14.1 & 1.199 & 0.154 & $1.51 \mathrm{E}-02$ \\
\hline 16 & basalt & 8 & 253 & 6.2 & 35.1 & 9.4 & 344.5 & 13.4 & 16.9 & 7.2 & 1.044 & 0.037 & $1.52 \mathrm{E}-04$ \\
\hline $17-1$ & $\begin{array}{l}\text { basalt } \\
+ \text { grt }\end{array}$ & 5 & 343.5 & 70.1 & 25.6 & 10.5 & 89.4 & 5.7 & 31.2 & 4.6 & 1.022 & -0.110 & $8.60 \mathrm{E}-05$ \\
\hline $17-2$ & mgt & 21 & 27.8 & 11.7 & 17.9 & 11.6 & 118.1 & 1.4 & 21.3 & 11.6 & 1.208 & -0.300 & $3.08 \mathrm{E}-02$ \\
\hline
\end{tabular}

The results of AMS measurements from the Yamansu open pit. Litho: Lithology, n: number of specimens, $K_{1}$ magnetic lineation, $K_{3}$ pole of the magnetic foliation, $D$, I, $\alpha_{95 \min }, \alpha_{95 \max }$ are declination, inclination, statistic confidence at 95\% level. $\mathrm{P}_{\mathrm{J}}$ :

Corrected anisotropy degree, T: Anisotropy shape parameter (Jelinek, 1981), and Km:

Mean bulk magnetic susceptibility ( $\left.\mathrm{SI}^{*} \mathrm{~g}^{-1}\right)$; mgt: magnetite rich rock; grt: massive garnet skarn; rss: retrograde stage skarn dominated by epidote, chlorite, tourmaline 
and K-feldspar.

FIGURE CAPTIONS

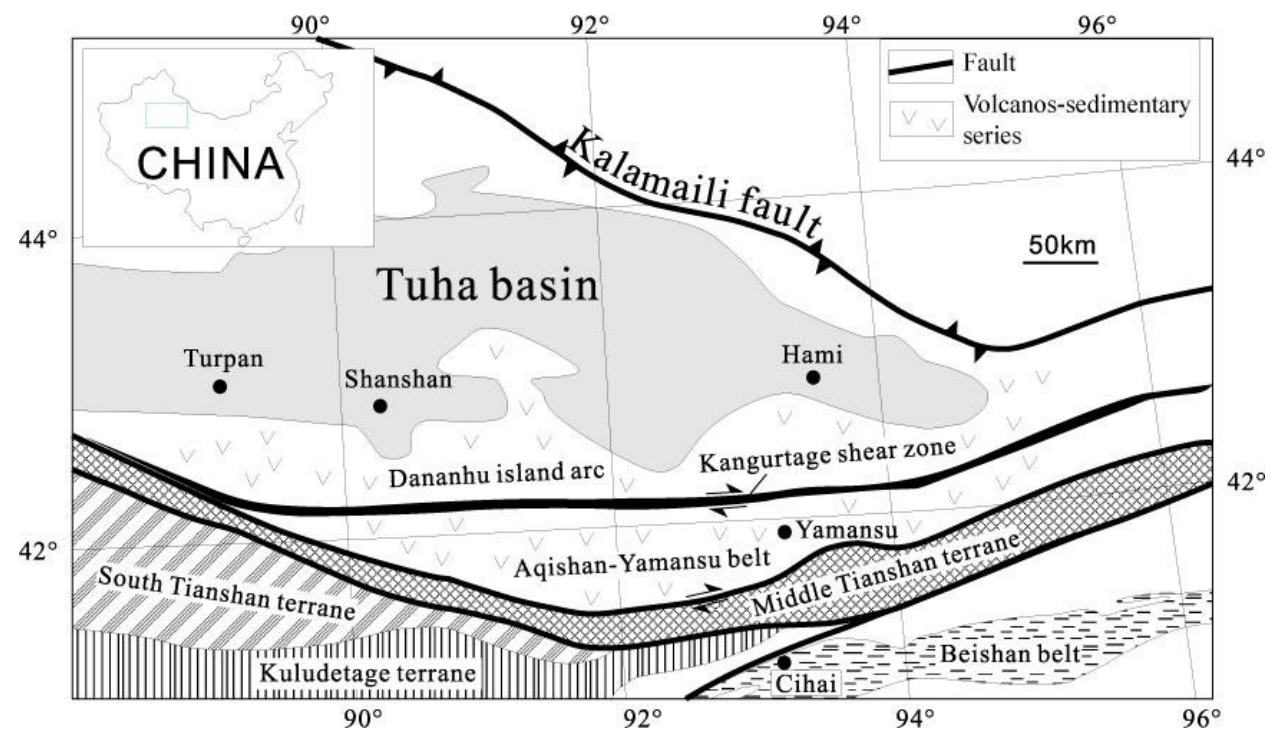

Fig. 1. Simplified location map showing for the Yamansu iron skarn deposit and the main tectonic units of eastern Tianshan (modified from Li (2004) and $\mathrm{Gu}$ et al., (2006)). 

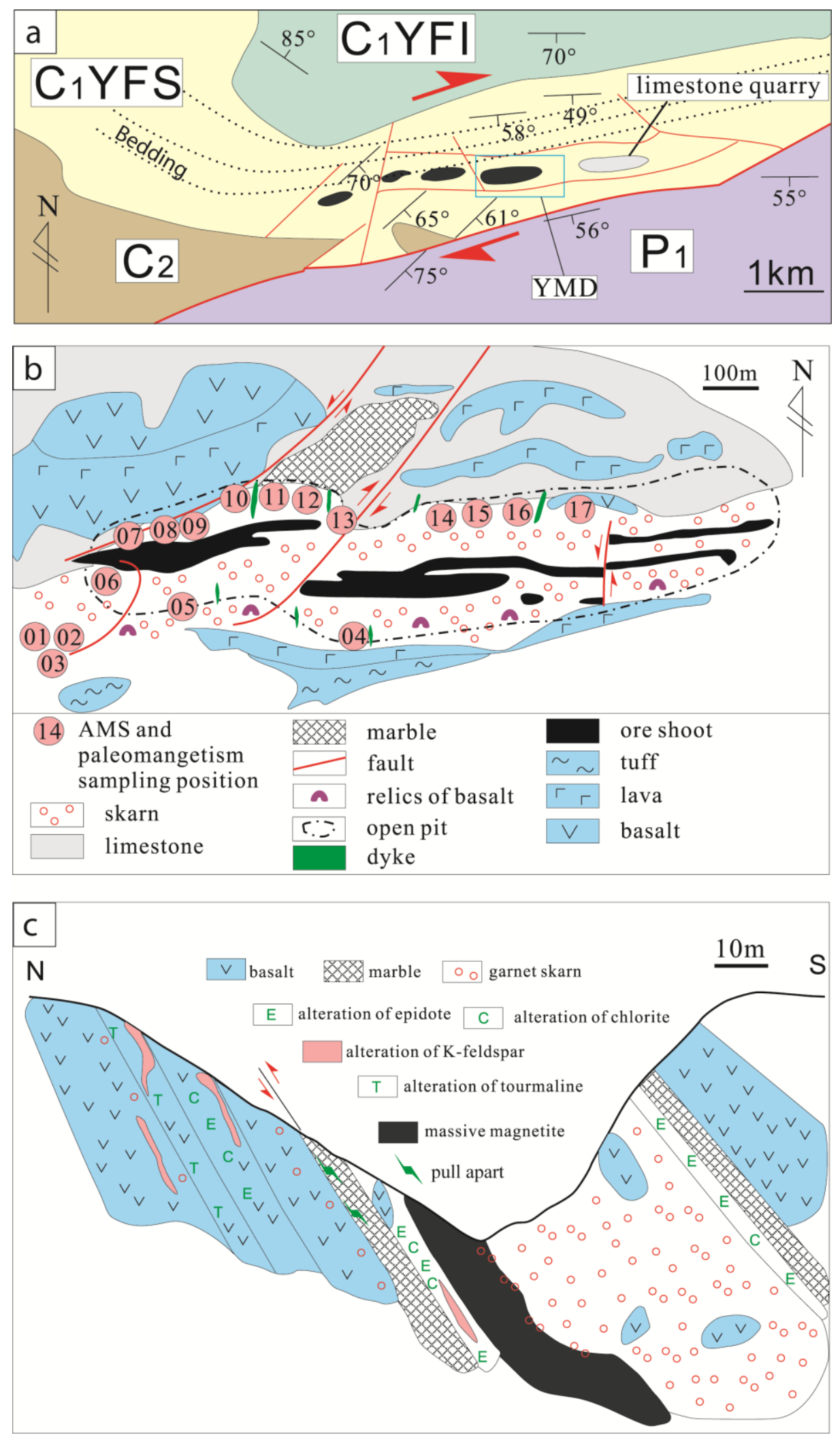
FIG. 2. Maps and cross section showing the Yamansu magnetite deposit (YMD). (a) geological map of Yamansu ore field (C1YFS: Lower Carboniferous Yamansu upper Formation, C1YFI: Lower Carboniferous Yamansu lower Formation, C2: Upper Carboniferous, P1: Lower Permian); (b) geological map of the Yamansu open pit; the sample names and positions used for AMS and paleomagnetic study are the pink circles with numbers inside; (c) cross section of the Yamansu deposit showing the development of a massive garnet skarn above the stratose magnetite ore body. Note the presence of basaltic relics within the garnet skarn. 


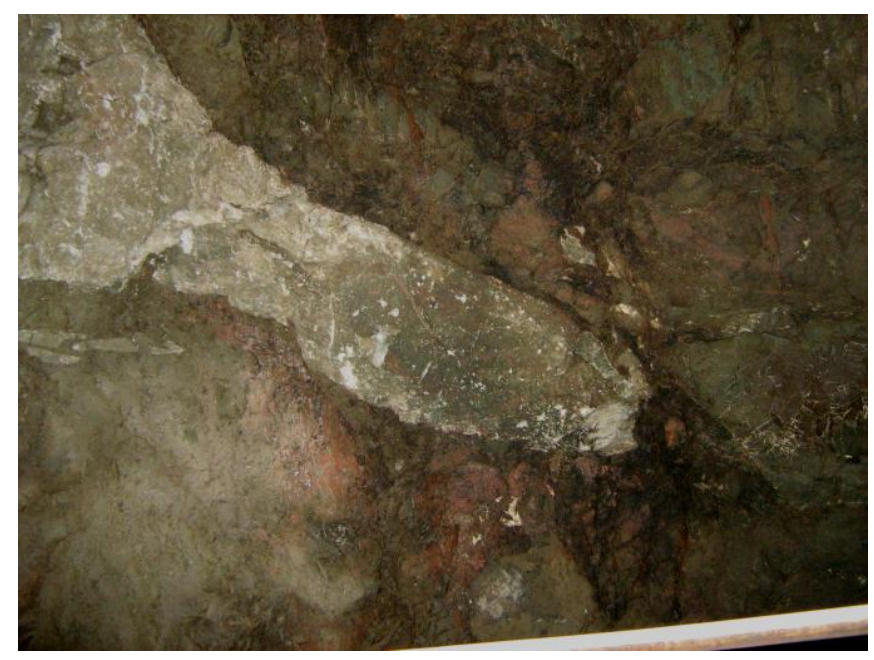

Fig. 3. Marble fragments within the strongly altered basaltic sill, suggesting mafic magmatic stoping and potential carbonate assimilation. Reddish ribbons consist of K-feldspar from potassium metasomatism. 
a
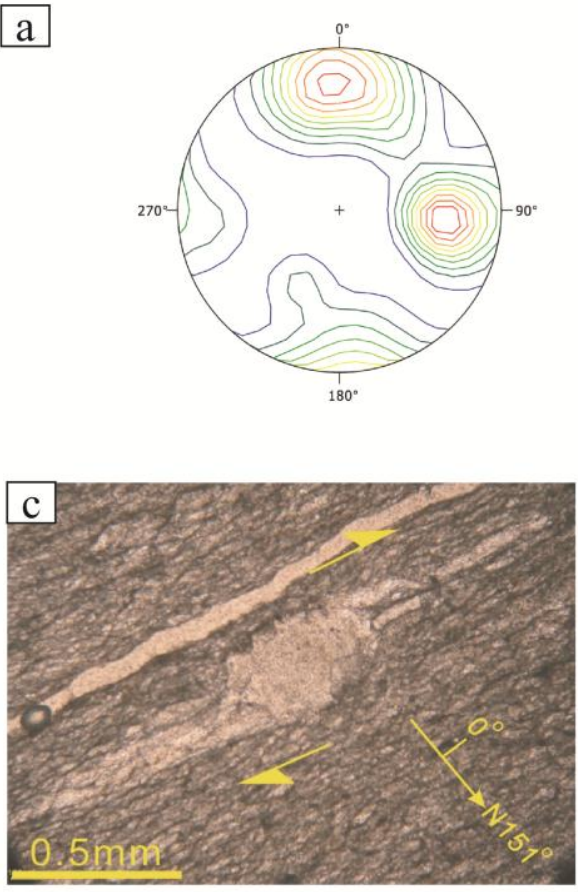

b
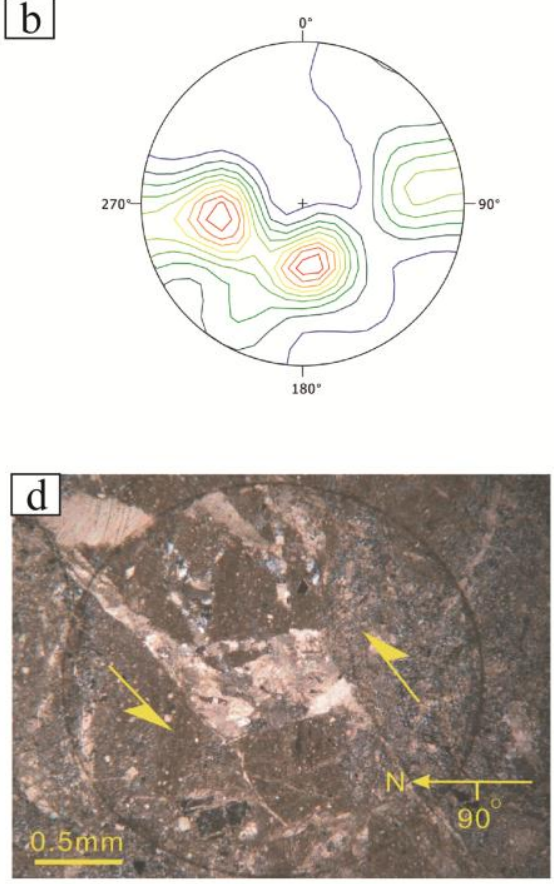
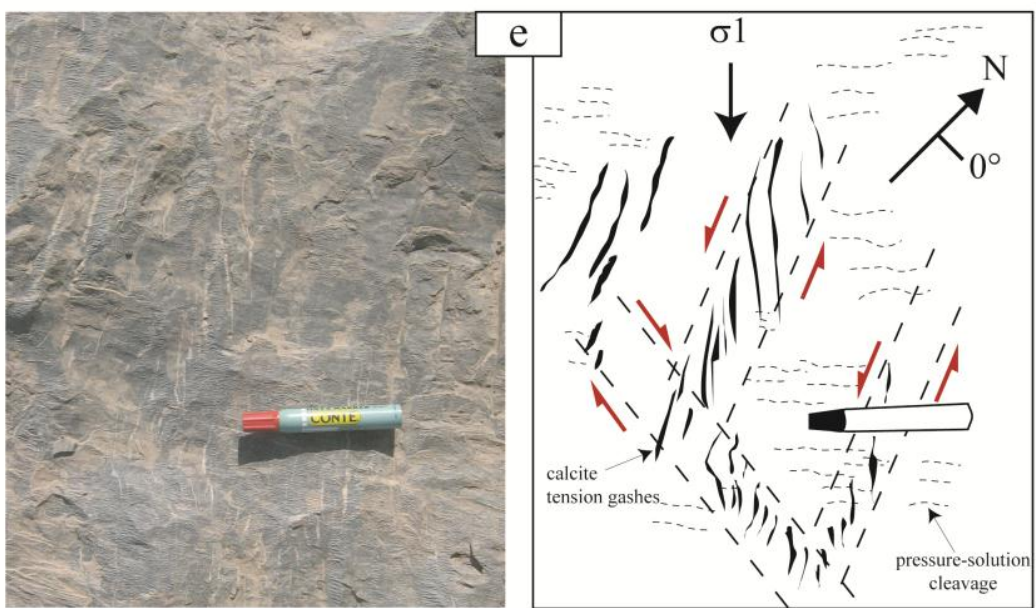

Fig. 4. Schmidt equal-area projection plots in the lower hemisphere of (a) poles of fault planes, 301 measurements, and (b) slickensides, 350 measurements; (c) 
Sigma-type calcite porphyroclast indicating dextral sense of shear; (d) pull-apart filled with calcite indicating a reverse sense of shear; (e) NW-SE compressive horizontal shortening attested from associated en echelon tension gashes, conjugated shear bands and pressure-solution cleavage in limestones north of the Yamansu pit.

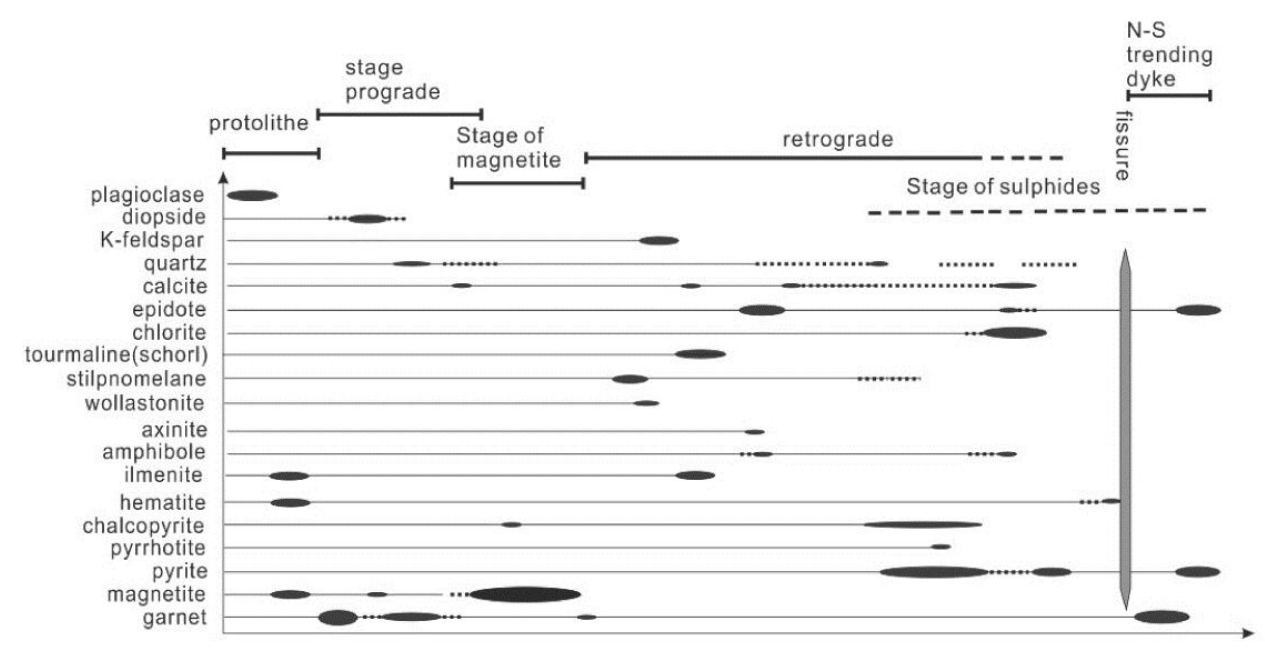

Fig. 5. Paragenetic sequence for the Yamansu skarn-related iron deposit. 

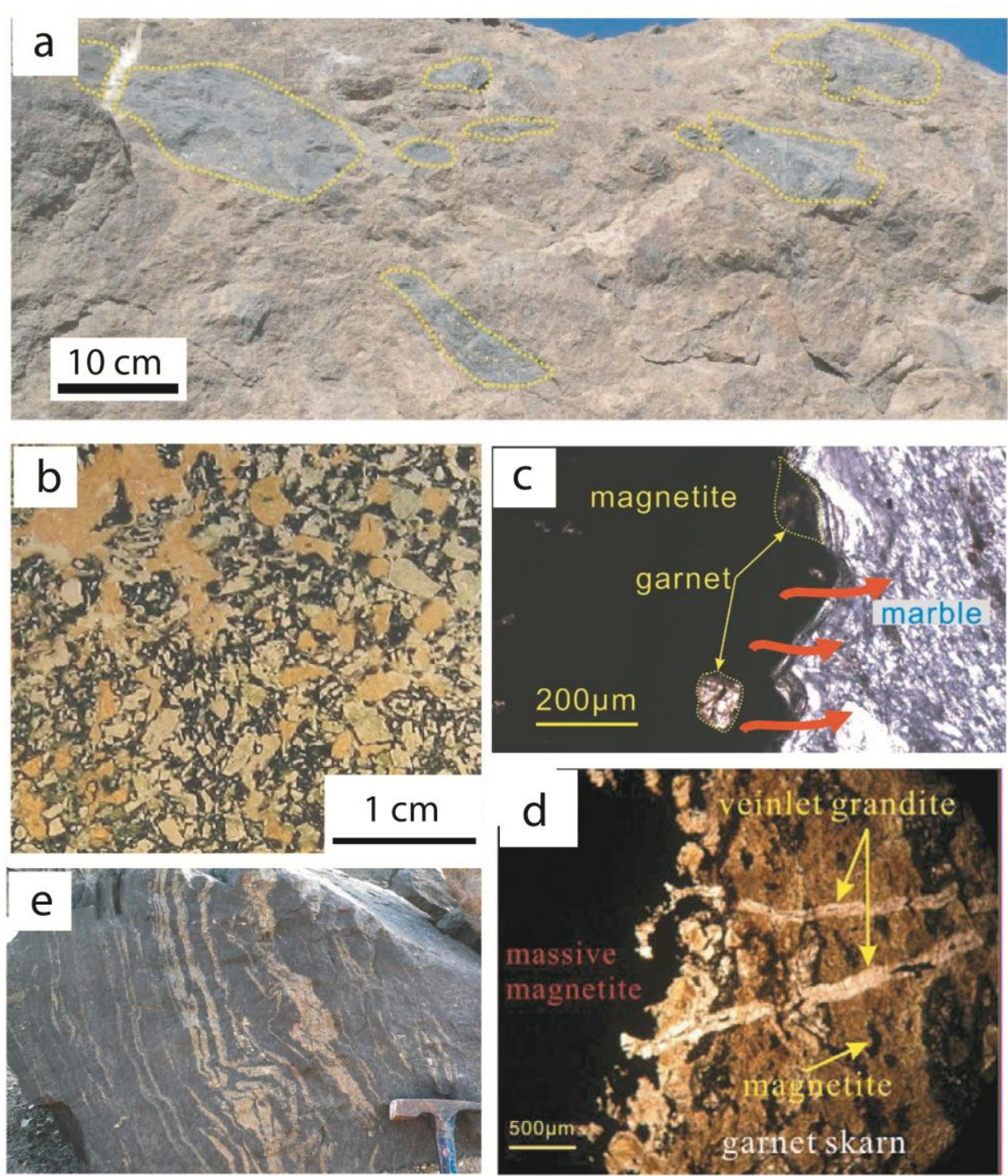

Fig. 6. Texture and mineralogy of the prograde and massive magnetite stages (modified from Li et al., 2014). (a) Relics of "basalt" (emphasized by dotted yellow lines) in massive reddish garnet skarn. (b) "Basalt" with plagioclase (in white) altered by andradite (in pink). Groundmass and disseminated magnetite are in black; (c) Front developed along the contact between magnetite and marble, where garnet is developed; transmitted plane polarised light. (d) Grandite vein crosscutting massive 
magnetite. (e) Rhythmic banding of garnet (reddish) and magnetite (black). 
a

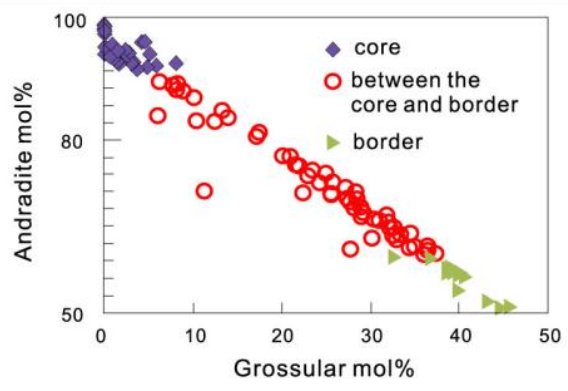

b

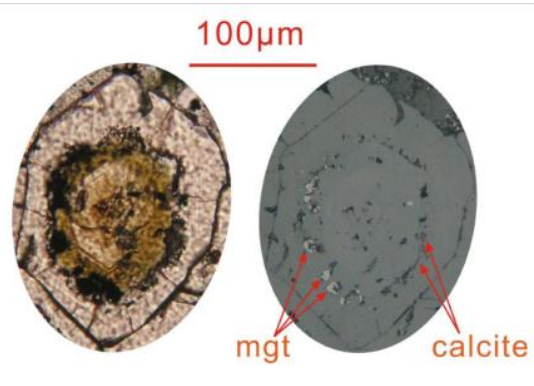

Fig. 7. (a) Electron microprobe analyses showing the compositional variations of garnet from andradite core to grandite border (Cameca SX50 electron microprobe hosted at BRGM equipped with four wavelength dispersion spectrometers WDS). (b) Euhedral garnet from the massive garnet skarn: left and right in transmitted and reflected polarised light, respectively, mgt for magnetite. 

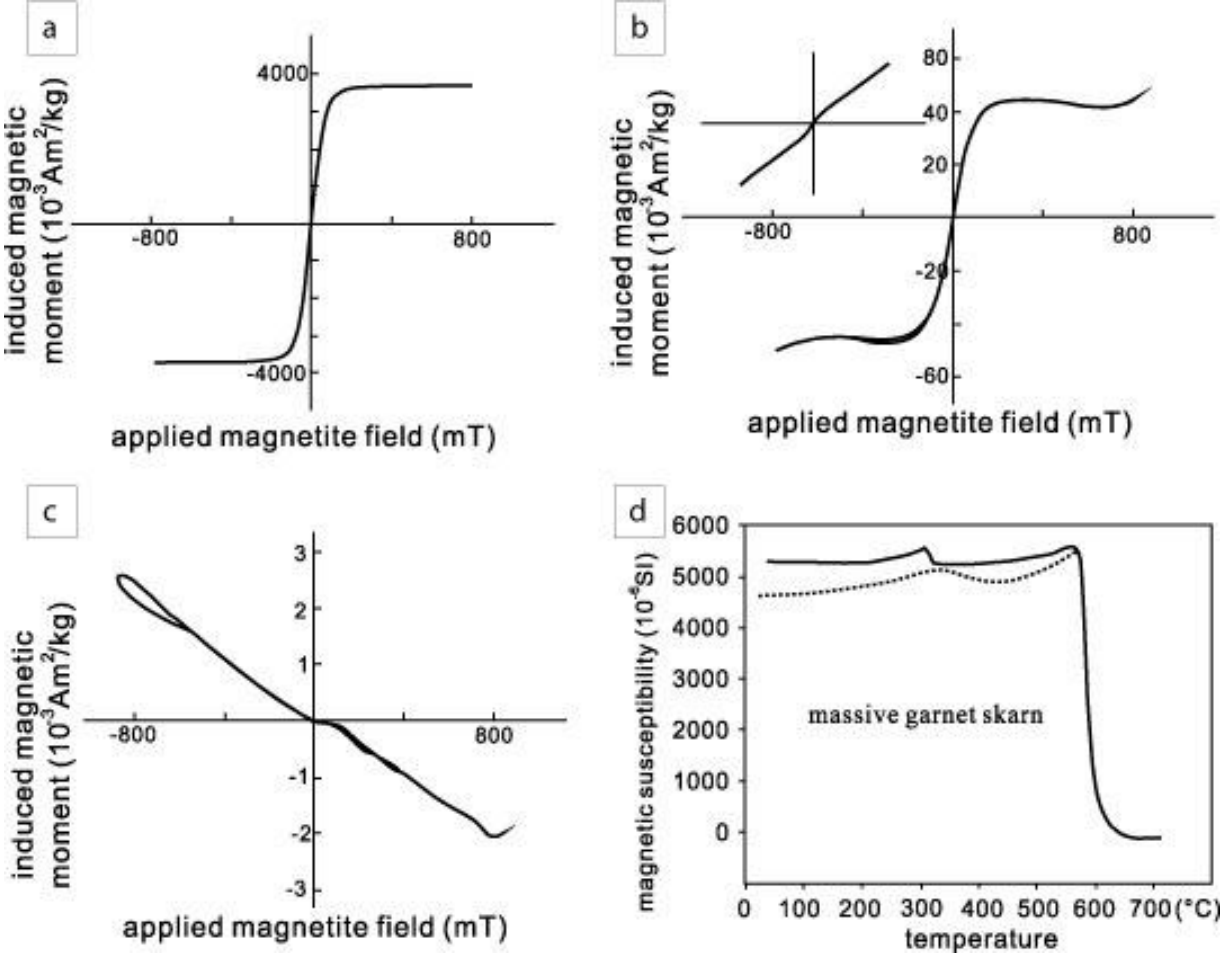

Fig. 8. Magnetic hysteresis loops for: (a) basalt, (b) massive garnet skarn (Loop without the contribution of paramagnetic s.s. components, up right: bulk data) and (c) marble. (d) Thermo-susceptibility curve for massive garnet skarn. The rapid decrease of magnetic susceptibility in (d) at about $580^{\circ} \mathrm{C}$ indicates the presence of magnetite. Solid (dotted) lines are the heating (cooling) curves. 


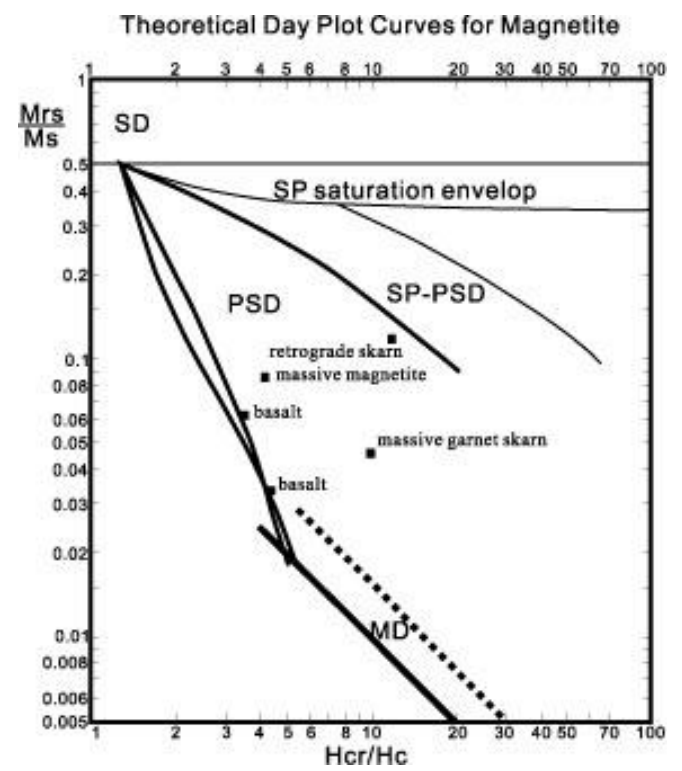

Fig. 9. Day plot diagram as the ratio of saturation remanence to saturation magnetization Mrs/Ms against the ratio of remanent coercive force to ordinary coercive force, modified by (Dunlop, 2002). 


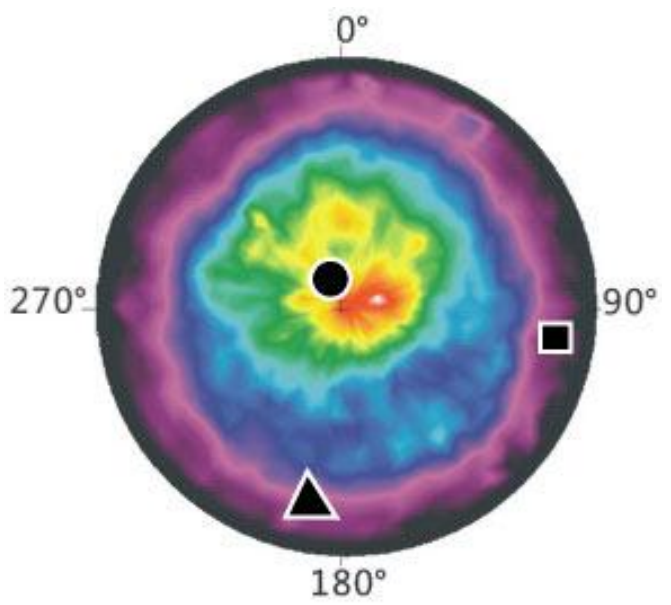

Fig. 10. Analysis of the marble texture where the stereogram shows the lattice preferred orientation of the (00012) pole plane, i.e. the calcite $\langle c\rangle$ axis. The colour levels indicate the diffracted X-ray intensities (purple: low and red: high). The anisotropy of magnetic susceptibility (AMS) measures are represented by a square ( $\mathrm{K}_{1}$ magnetic lineation), triangle $\left(\mathrm{K}_{2}\right)$ and circles ( $\mathrm{K}_{3}$ pole of magnetic foliation). 


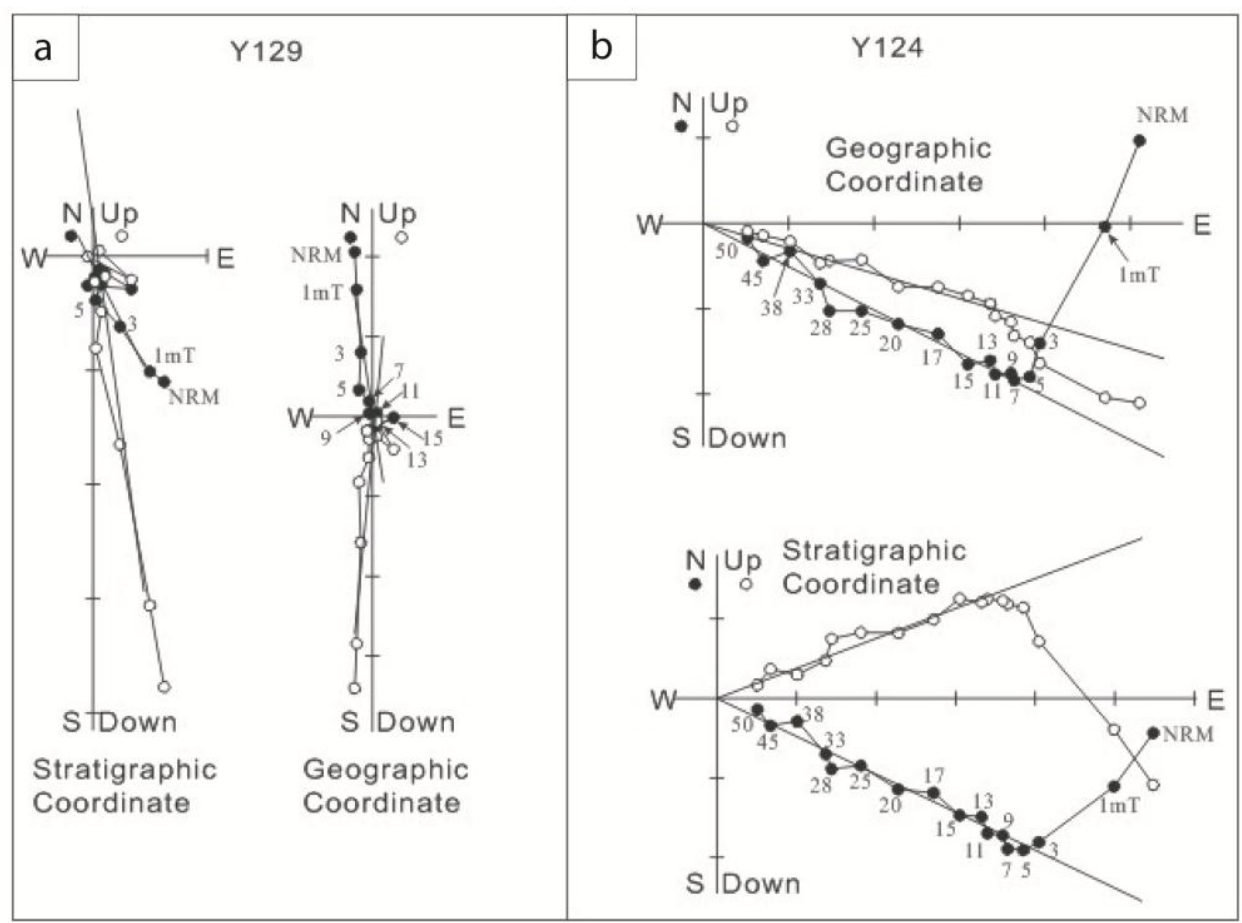

Fig. 11. Paleomagnetic measurement results from the Yamansu skarn deposit. Orthogonal projection of sample progressive AF demagnetization (Zijderveld, 1967) in geographic and stratigraphic coordinates. White and black circles represent vertical and horizontal planes, respectively. Numbers adjacent to data points indicate peak demagnetizing field in $\mathrm{mT}$. 

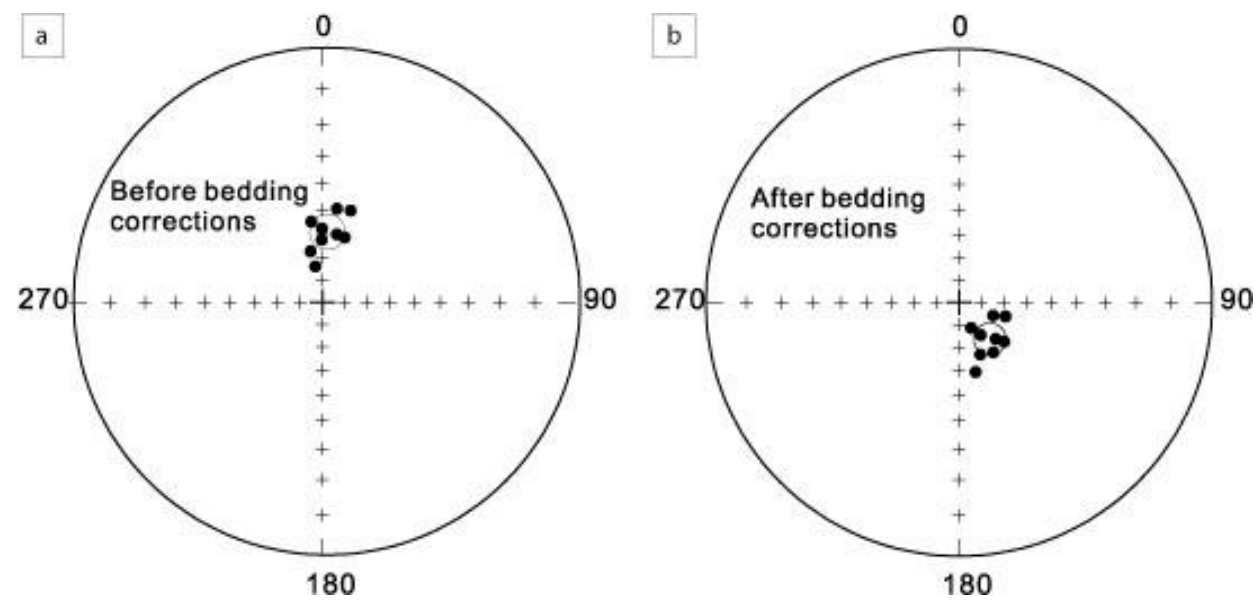

Fig. 12. Equal-area stereoplots for the weaker viscous remanence that is close to the present Earth's field direction. 

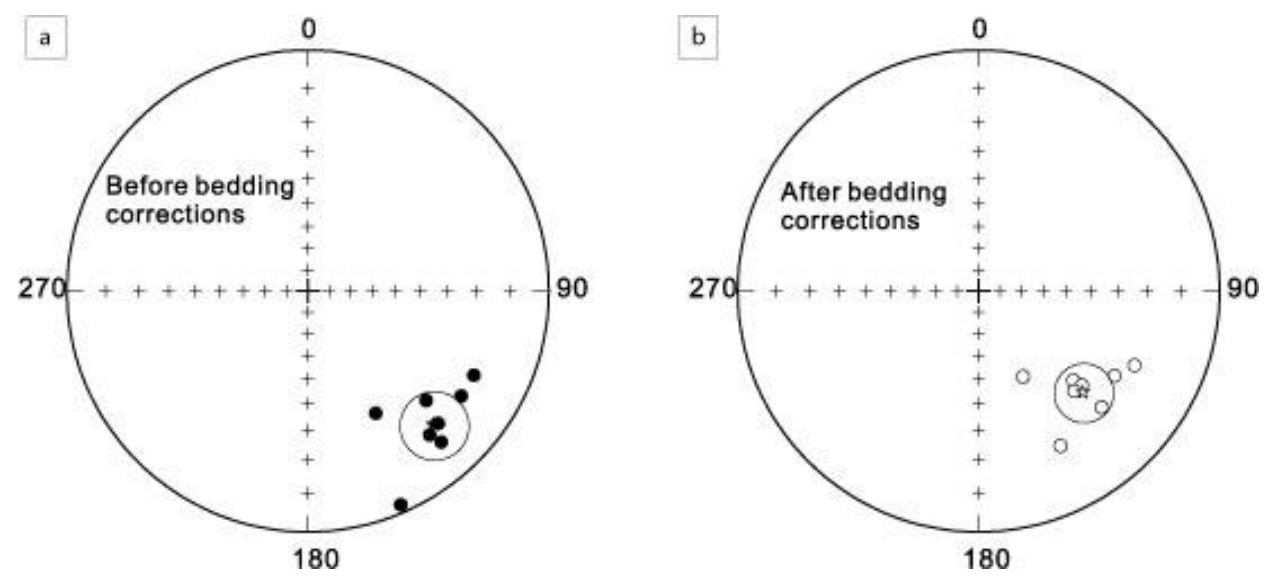

Fig. 13. Equal-area stereoplots for "hard" remanence components. White (black) circles represent reversed (normal) polarities of the mean direction. The left and right show the direction in geographic coordinates and stratigraphic corrected coordinates, respectively. 

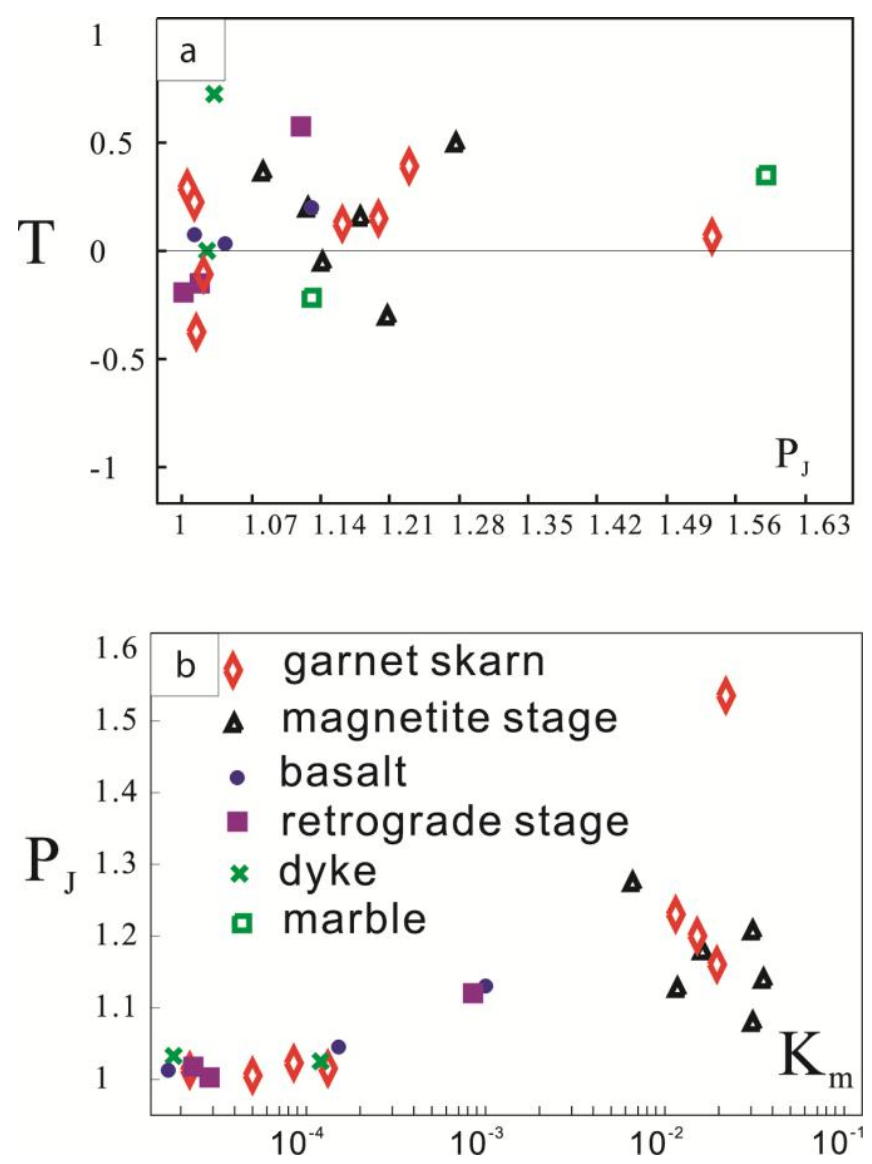

Fig. 14. AMS scalar parameters for sites grouped by lithologies. (a): $\mathrm{T}$ shape parameter vs. $\mathrm{P}_{\mathrm{J}}$ corrected anisotropy degree; and; (b) $\mathrm{P}_{\mathrm{J}}$ corrected degree of anisotropy vs. Km, mean bulk magnetic susceptibility in SI.g ${ }^{-1}$. 

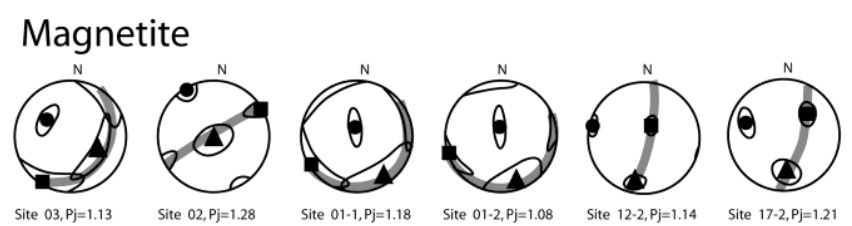

Marble

Garnet Skarn
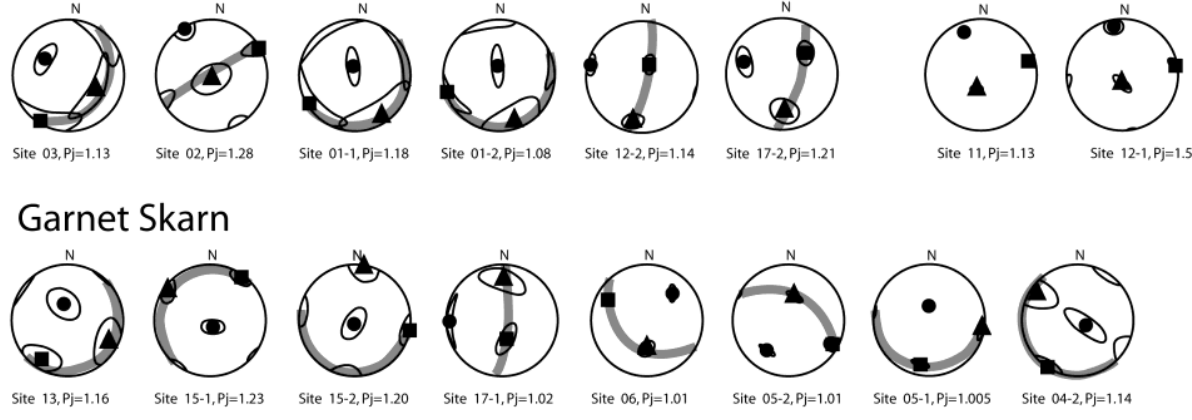

Site $11, \mathrm{Pj}=1.13$

Site $12-1, \mathrm{Pj}=1.59$
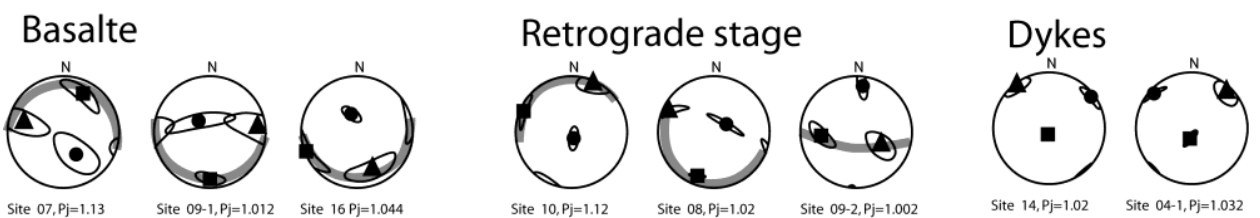

Fig. 15. AMS results presented in equal-area projection. Squares, triangle and circles stand for $\mathrm{K}_{1}$ (magnetic lineation), $\mathrm{K}_{2}$ and $\mathrm{K}_{3}$ (pole of magnetic foliation), respectively. Confidence ellipses at 95\% level are drawn around site-mean direction. All sites are tilt-corrected coordinates except the sites of dyke and marble. Tilt correction is based on stratification plane marked by the ripple marks in limestone $\left(165^{\circ} \angle 49^{\circ}\right)$. Grey lines in stereoplots give the magnetic foliation. 


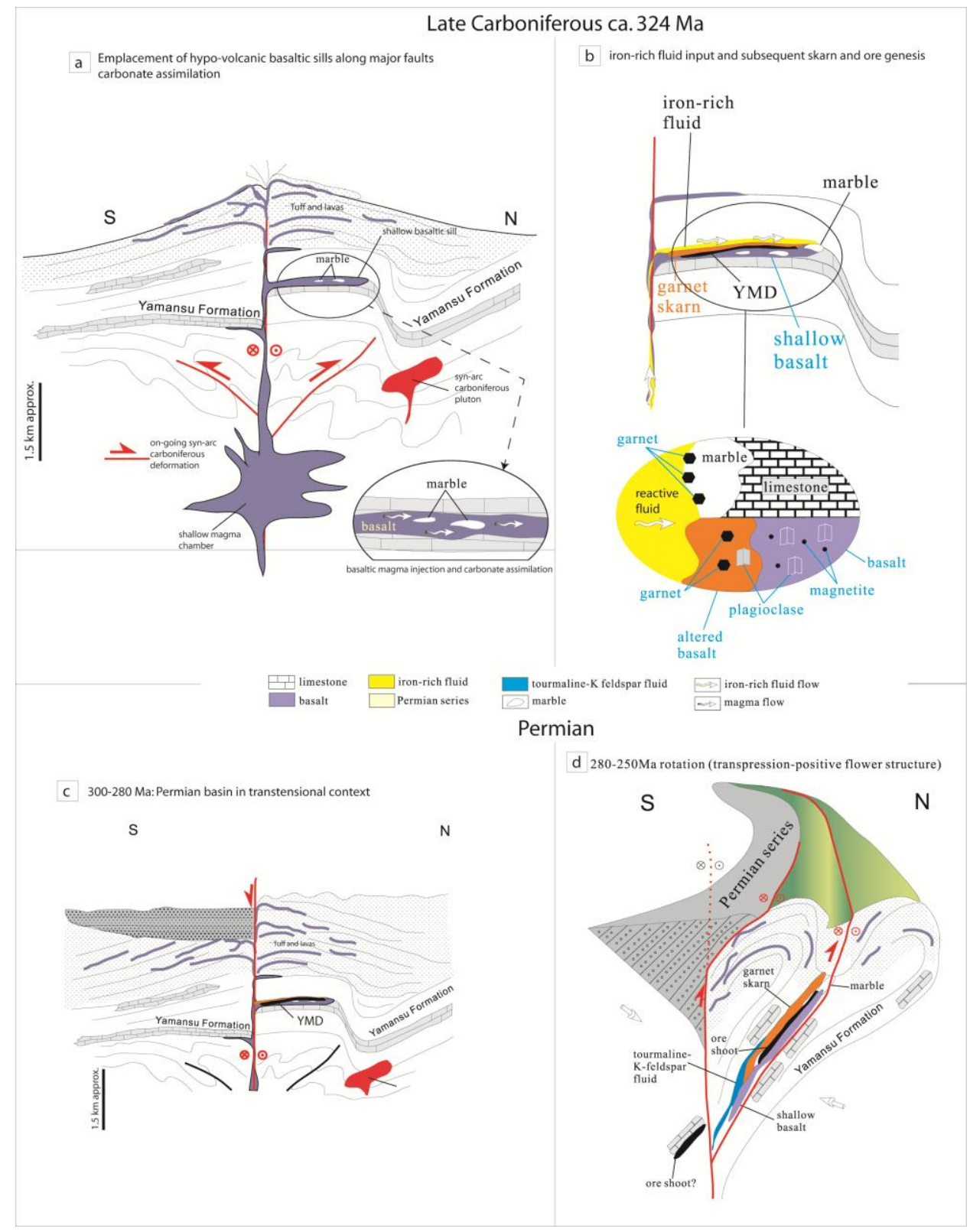

Fig. 16. Metallogenic model of the Yamansu iron deposit 